\title{
cAMP Response Element-Binding Protein Is Required for Dopamine-Dependent Gene Expression in the Intact But Not the Dopamine-Denervated Striatum
}

\author{
Malin Andersson, ${ }^{1}$ Christine Konradi, ${ }^{2}$ and M. Angela Cenci ${ }^{1}$ \\ ${ }^{1}$ Department of Physiological Sciences, Neurobiology Division, Lund University, Wallenberg Neuroscience Centre, 22184 \\ Lund, Sweden, and 2Laboratory of Neuroplasticity, McLean Hospital and Harvard Medical School, Belmont, \\ Massachusetts 02478
}

The cAMP response element-binding protein (CREB) is believed to play a pivotal role in dopamine (DA) receptor-mediated nuclear signaling and neuroplasticity. Here we demonstrate that the significance of CREB for gene expression depends on the experimental paradigm. We compared the role of CREB in two different but related models: L-DOPA administration to unilaterally 6-hydroxydopamine lesioned rats, and cocaine administration to neurologically intact animals. Antisense technology was used to produce a local knockdown of CREB in the lateral caudate-putamen, a region that mediates the dyskinetic or stereotypic manifestations associated with L-DOPA or cocaine treatment, respectively. In intact rats, CREB antisense reduced both basal and cocaine-induced expression of c-Fos, FosB/ $\triangle F o s B$, and prodynorphin mRNA. In the DA-denervated striatum, CREB was not required for L-DOPA to induce these gene products, nor did CREB contribute considerably to DNA bind- ing activity at cAMP responsive elements (CREs) and CRE-like enhancers. $\triangle$ FosB-related proteins and JunD were the main contributors to both CRE and AP-1 DNA-protein complexes in L-DOPA-treated animals. In behavioral studies, intrastriatal CREB knockdown caused enhanced activity scores in intact control animals and exacerbated the dyskinetic effects of acute L-DOPA treatment in 6-OHDA-lesioned animals. These data demonstrate that CREB is not required for the development of L-DOPA-induced dyskinesia in hemiparkinsonian rats. Moreover, our results reveal an unexpected alteration of nuclear signaling mechanisms in the parkinsonian striatum treated with L-DOPA, where AP-1 transcription factors appear to supersede CREB in the activation of CRE-containing genes.

Key words: Parkinson's disease; immediate-early genes; direct pathway; opioid precursor; psychostimulant; sensitization; protooncogenes; motor stereotypies
Drugs that stimulate dopamine (DA) receptors have the potential to produce long-lasting behavioral and neural alterations. L-DOPA pharmacotherapy of Parkinson's disease is associated with a high incidence of motor complications, such as wearing-off fluctuations and dyskinesias, the development of which is closely paralleled by changes in striatal gene expression (for review, see Calon et al., 2000). Animal studies have shown that both L-DOPA-induced dyskinesia and DA-dependent stereotypies are associated with an induction of prodynorphin (PDyn) and fos family genes in striatal projection neurons of the "direct pathway" (for review, see Graybiel et al., 2000). Multiple lines of evidence suggest that such an induction is mediated by cAMP response element-binding protein (CREB) phosphorylation through activation of $\mathrm{D}_{1}$ receptors and protein kinase A (PKA) (Cole et al., 1994, 1995; Simpson and McGinty, 1995; Konradi et al., 1996). Phosphorylated CREB has been detected in the DA-denervated rat striatum after treatment with L-DOPA (Cole et al., 1994) and in the intact striatum after psychostimulant drug administration

Received July 11, 2001; revised Sept. 19, 2001; accepted Sept. 24, 2001.

This study was supported by grants from the Swedish Medical Research Council (Contract K2000-33X-13480-01A to M.A.C.), the Swedish Association of the Neurologically Disabled, the Craaford Foundation, the Greta and Johan Kock Foundations, the Thorsten and Elsa Segerfalk Foundation, the Swedish Society For Medical Research, Ake Wiberg Foundation, and the National Institute of Drug Abuse (Grant DA07134).We thank Ulla Jarl for technical assistance and Thomas Herdegen for helpful discussion.

Correspondence should be addressed to Dr. Angela Cenci Nilsson, Wallenberg Neuroscience Centre, Neurobiology Division, BMC A11, S-221 84 Lund, Sweden. E-mail: Angela.Cenci_Nilsson@mphy.lu.se.

Copyright (C) 2001 Society for Neuroscience $\quad 0270-6474 / 01 / 219930-14 \$ 15.00 / 0$
(Cole et al., 1995; Konradi et al., 1996). Moreover, amphetamineinduced striatal c-Fos expression can be blocked by knockdown of CREB mRNA (Konradi et al., 1996). Furthermore, in striatal protein extracts, CREB accounts for DNA binding activity at cAMP responsive element (CRE) sites (Cole et al., 1995; Konradi et al., 1996), which are present in both the $c$-fos (Curran et al., 1987) and the PDyn promoter (Douglass et al., 1994). These and other findings have prompted the notion of CREB as a critical mediator of drug-induced neuroplasticity in the striatum (for review, see Pierce and Kalivas, 1997; Calon et al., 2000). However, the requirement of CREB for DA receptor-induced cellular and behavioral plasticity may not hold true in all experimental paradigms.

Here, we have used antisense technology to assess whether L-DOPA-induced changes in fos and PDyn gene expression, and/or the concomitant dyskinetic manifestations in hemiparkinsonian rats (Cenci et al., 1998; Andersson et al., 1999), can be blocked by CREB knockdown. We have also performed a parallel experiment to investigate whether CREB is required for both basal and cocaine-induced expression of the same genes in neurologically intact animals. The information provided by antisense experiments was complemented by an analysis of DNA-protein interactions in striatal protein extracts. In agreement with currently held notions, CREB was found to be essential for cocaineinduced gene expression in the intact striatum, where it accounted for most protein binding activity to CRE-like elements. By contrast, in the DA-denervated striatum, CREB was not required for L-DOPA to induce $c$-fos, fos $\mathrm{B}$, and PDyn gene 


\begin{tabular}{|c|c|c|c|}
\hline & Drug dose & Oligonucleotide & $\begin{array}{l}\text { Number of } \\
\text { animals }\end{array}$ \\
\hline \multicolumn{4}{|l|}{ 6-OHDA-lesioned rats } \\
\hline Saline & & No & 20 \\
\hline Acute L-DOPA & $3 \mathrm{mg} / \mathrm{kg}$ & No & 3 \\
\hline Acute L-DOPA & $5 \mathrm{mg} / \mathrm{kg}$ & No & 5 \\
\hline Acute L-DOPA & $5 \mathrm{mg} / \mathrm{kg}$ & CREB AS & 5 \\
\hline Acute L-DOPA & $5 \mathrm{mg} / \mathrm{kg}$ & Control oligo & 5 \\
\hline Acute L-DOPA & $8 \mathrm{mg} / \mathrm{kg}$ & No & 17 \\
\hline Acute L-DOPA & $8 \mathrm{mg} / \mathrm{kg}$ & CREB AS & 16 \\
\hline Acute L-DOPA & $8 \mathrm{mg} / \mathrm{kg}$ & Control oligo & 16 \\
\hline Chronic L-DOPA & $8 \mathrm{mg} \cdot \mathrm{kg}^{-1} \cdot \mathrm{d}^{-1}$ & No & 9 \\
\hline Chronic L-DOPA & $8 \mathrm{mg} \cdot \mathrm{kg}^{-1} \cdot \mathrm{d}^{-1}$ & CREB AS & 9 \\
\hline Chronic L-DOPA & $8 \mathrm{mg} \cdot \mathrm{kg}^{-1} \cdot \mathrm{d}^{-1}$ & Control oligo & 9 \\
\hline \multicolumn{4}{|l|}{ Intact rats } \\
\hline Saline & & No & 15 \\
\hline Saline & & CREB AS & 7 \\
\hline Saline & & Control oligo & 6 \\
\hline Acute cocaine & $15 \mathrm{mg} / \mathrm{kg}$ & No & 7 \\
\hline Acute cocaine & $15 \mathrm{mg} / \mathrm{kg}$ & CREB AS & 19 \\
\hline Acute cocaine & $15 \mathrm{mg} / \mathrm{kg}$ & Control oligo & 19 \\
\hline Acute cocaine & $30 \mathrm{mg} / \mathrm{kg}$ & No & 5 \\
\hline Acute cocaine & $30 \mathrm{mg} / \mathrm{kg}$ & CREB AS & 6 \\
\hline Acute cocaine & $30 \mathrm{mg} / \mathrm{kg}$ & Control oligo & 8 \\
\hline Chronic cocaine & $30 \mathrm{mg} \cdot \mathrm{kg}^{-1} \cdot \mathrm{d}^{-1}$ & No & 5 \\
\hline
\end{tabular}

expression, and both CRE- and AP-1-binding activity was mainly accounted for by $\Delta$ FosB-related proteins and JunD. The present results show that CREB is not a critical mediator of L-DOPAinduced gene expression changes in the parkinsonian striatum, where AP-1 transcription factors appear to supersede CREB in the activation of CRE-containing genes.

\section{MATERIALS AND METHODS}

Subjects. Female Sprague Dawley rats (BK Universal, Stockholm, Sweden; $\sim 225$ gm body weight at the beginning of experiment) were housed under a $12 \mathrm{hr}$ light/dark cycle with ad libitum access to food and water. The number of animals and experimental groups in the present study is shown in Table 1.

Dopamine denervating lesions. All rats receiving L-DOPA treatment had sustained unilateral injections of 6-hydroxydopamine (6-OHDA$\mathrm{HCl}$; Sigma-Aldrich Sweden AB) into the right ascending DA fiber bundle at least 4 weeks before drug treatment, as described previously (Cenci et al., 1998). Briefly, 6-OHDA was dissolved in $0.02 \%$ ascorbic acid/saline at a concentration of $3 \mu \mathrm{g} / \mu \mathrm{l}$ and injected at the following coordinates (in $\mathrm{mm}$, relative to bregma and the dural surface): (1) anterior $(\mathrm{A})=-4.0$, lateral $(\mathrm{L})=-0.8$, ventral $(\mathrm{V})=-8.0$, toothbar $=$ $+3.4(6 \mu \mathrm{g}$ deposit); and (2) $\mathrm{A}=-4.4, \mathrm{~L}=-1.2, \mathrm{~V}=-7.8$, toothbar $=$ -2.3 ( $7.5 \mu \mathrm{g}$ deposit).

To evaluate the extent of DA denervation, the rats were tested for amphetamine-induced rotation at 2 weeks after lesion. Turning behavior was recorded in an automated rotometer over a $90 \mathrm{~min}$ period after an injection of $5 \mathrm{mg} / \mathrm{kg}$ dexamphetamine sulfate (Apoteksbolaget Sweden $\mathrm{AB}$ ). Only rats that showed more than seven full turns per minute ipsilateral to the lesion (corresponding to $>97 \%$ DA depletion in the caudate-putamen) (Schmidt et al., 1982) were selected for the study.

Drugs. DA-denervated rats received L-DOPA methyl ester (3-8 $\mathrm{mg} /$ kg, i.p.; Sigma-Aldrich) mixed with the peripheral DOPA-decarboxylase inhibitor, benserazide hydrochloride $(15 \mathrm{mg} / \mathrm{kg}$; kindly provided by Hoffman-La Roche, Basel, Switzerland). Neurologically intact rats were injected with cocaine (15 or $30 \mathrm{mg} / \mathrm{kg}$, i.p.; Apoteksbolaget Sweden AB). All drugs were dissolved in physiological saline and injected immediately. Animals were killed at $3 \mathrm{hr}$ after injection. This survival period was chosen on the basis of previous literature showing that upregulation of
Fos family proteins and PDyn mRNA can be detected in the striatum at this time after DA agonist administration (Hurd and Herkenham, 1992; Andersson et al., 1999; Cenci et al., 1999).

Antisense experiments. The CREB antisense (AS; 5'-TGGTCATCTAGTCACCGGTG-3') and CREB sense (5'-CACCGGTGACTAGATGACCA-3') sequences were published previously (Konradi et al., 1994). The "scrambled" control sequence was a random assortment of the bases that composed the AS (5'-TGCTGAACTTGTCGCCAGTG$\left.3^{\prime}\right)$. This sequence showed no homology to any known mammalian gene. All oligonucleotides were partially phosphorothioate modified (sulfur substitutions at both the $5^{\prime}$ and $3^{\prime}$ terminal phosphodiester linkage) and were purchased from Scandinavian Gene Synthesis.

For single injections, oligonucleotides were dissolved in sterile PBS at a concentration of $2.5 \mathrm{~mm}$. One microliter of the solution was injected over $2 \mathrm{~min}$ (the cannula being left in place for an additional $2 \mathrm{~min}$ ) at the following coordinates (in mm, relative to bregma and the dural surface): $\mathrm{A}=+0.6, \mathrm{~L}= \pm 3.5, \mathrm{~V}=-4.7$, tooth bar at -2.3 . Surgery was performed on rats anesthetized with a mixture of Hypnorm (Janssen Pharmaceutical) and Dormicum (Hoffman-La Roche) that was dissolved in sterile water $(1: 1: 2$ solution; $2.7 \mathrm{ml} / \mathrm{kg}$, i.p). Analgesic treatment (Temgesic, Apoteksbolaget AB; $0.167 \mathrm{ml} / \mathrm{kg}$ body weight, s.c.,) was given $\sim 20 \mathrm{~min}$ before the rats awakened.

For continuous infusions, oligonucleotides were dissolved in sterile PBS at $0.2 \mathrm{~mm}$ concentration and infused through Alzet osmotic minipumps (Model 2002, 14 d duration; Alza Corporation, Palo Alto, CA) into the striatum at a rate of $0.5 \mu \mathrm{l} / \mathrm{hr}(2.5 \mathrm{nmol}$ in $12 \mu \mathrm{l}$ per day $)$ Implantation surgery was performed on anesthetized rats as described above. The injection cannulas were implanted in the lateral caudateputamen at the following coordinates; $\mathrm{A}=+0.6, \mathrm{~L}=+4.0, \mathrm{~V}=-5.0$, tooth bar at -2.3 . The cannulas were secured to the skull using screws and dental acrylic. The reservoirs were inserted subcutaneously in the neck. Rats were treated with antibiotics (Borgal, 1:500 in the drinking water; Hoechst) from $1 \mathrm{~d}$ before to $6 \mathrm{~d}$ after pump implantation.

Dyskinesia and stereotypy rating. An investigator who was completely unaware of the rat group membership (experimentally blinded) performed all behavioral testing. L-DOPA-induced abnormal involuntary movements (AIMs) were rated using a rat dyskinesia scale that we introduced recently (Cenci et al., 1998; Andersson et al., 1999; Lee et al., 2000). This scale only takes into account purposeless movements that are clearly abnormal for the rat, whereas enhanced manifestations of normal motor activities, such as grooming, gnawing, rearing, and sniffing, are not included in the rating. Briefly, rats were observed individually for $1 \mathrm{~min}$ every $20 \mathrm{~min}$ after an injection of L-DOPA. Each rat was scored on a severity scale from 0 to 4 on each of four subtypes of dyskinetic-like movements (axial, orolingual, forelimb, and locomotive AIMs).

Motor activity and stereotypies were rated according to Creese and Iversen (1973). Rats were observed for $30 \mathrm{sec}$ every $10 \mathrm{~min}$ after an injection of cocaine or saline. Every rat was scored on a scale from 0 to $6(0=$ asleep or stationary; $1=$ active; $2=$ very active with bursts of intense sniffing; $3=$ stereotyped sniffing along a fixed path in the cage; $4=$ stereotyped sniffing or rearing in a fixed location; $5=$ stereotyped behavior in one location with bursts of gnawing and licking; and $6=$ continual gnawing and licking of the cage bars in a fixed location). Note that scores of $0-2$ in this scale reflect generic motor activation, whereas scores $\geq 3$ reflect a clearly stereotypic behavior (i.e., repetition of single or multiple movements according to an inflexible pattern). Dyskinesia and activity-stereotypy ratings were performed at 60-120 min after drug injection, corresponding to the peak of the time-action curve for both L-DOPA (Lee et al., 2000) and cocaine (our unpublished data).

Histological procedures. The rats were deeply anesthetized with sodium pentobarbitone $(240 \mathrm{mg} / \mathrm{kg}$, i.p.; Apoteksbolaget $\mathrm{AB})$ and killed by decapitation. The brains were rapidly removed and frozen on dry ice. Coronal sections (16 $\mu \mathrm{m}$ thick) were cut through the striatum using a cryostat, thaw-mounted onto microscope slides (SuperFrost Plus; Menzel Glazer), and stored at $-20^{\circ} \mathrm{C}$.

Screening for unspecific tissue damage after oligonucleotide delivery to the striatum. In the antisense study, one series of sections per animal was stained using cresyl violet to verify the location of the cannula track and the extent of the surrounding inflammation. The amount of monocyte infiltration at the injection site did not differ between the three oligonucleotide sequences used in this study. A total of eight animals showing severe inflammation and hemorrhage were excluded from the study.

To assess ongoing neuronal death, another series of sections was stained using Fluoro-Jade B histochemistry according to Schmued and Hopkins (2000). Briefly, sections were treated with $1 \% \mathrm{NaOH}$ in $80 \%$ 
ethanol for $5 \mathrm{~min}$, rinsed sequentially in ethanol and water, transferred to a solution of $0.06 \%$ potassium permanganate for $10 \mathrm{~min}$, and rinsed in water. Thereafter, the sections were incubated for $20 \mathrm{~min}$ with FluoroJade B (Histo-Chem Inc., AR; $0.0004 \%$ in $0.1 \%$ acetic acid/water), rinsed repeatedly, and dried in a slide warmer. Cells along the needle track in the striatum and the cortex were clearly fluorescent at $32 \mathrm{hr}$ after a single oligonucleotide injection. In contrast, no fluorescent neurons could be detected after $14 \mathrm{~d}$ of continuous oligonucleotide infusion, indicating that the oligonucleotides per se did not exert cytotoxic effects during the infusion time.

Immunohistochemistry. Immunohistochemistry was performed using a standard peroxidase-based method (Vectastain Elite ABC Kit, Vector Laboratories, Burlingame, CA) with 3,3'-diaminobenzidine (SigmaAldrich Sweden AB) as a chromogen.

The following primary antisera were used at the indicated dilutions: CREB (1:5000; rabbit polyclonal from Upstate Biotechnology, Lake Placid, NY); c-Fos (1:1000, sheep polyclonal from Sigma-Genosys); FosB/ $\Delta$ FosB (1:15000, rabbit polyclonal from Santa Cruz Biotechnology, Santa Cruz, CA); neuron-specific nuclear protein (NeuN, 1:100, mouse monoclonal from Chemicon, Temecula, CA); and JunD (1:5000, rabbit polyclonal from Santa Cruz Biotechnology). Before immunohistochemistry, cryostat sections were fixed by a $10 \mathrm{~min}$ immersion in phosphatebuffered $4 \%$ paraformaldehyde at $4^{\circ} \mathrm{C}, \mathrm{pH} 7.4$, rinsed three times in potassium PBS, and incubated with an avidin-biotin blocking kit (Vector Laboratories; $1 \mathrm{hr}$ incubation in each solution, avidin and biotin).

In situ hybridization histochemistry. In situ hybridization histochemistry (ISHH) was performed using synthetic oligomers complementary to nucleotides 934-982 of the cloned PDyn gene (Civelli et al., 1985), nucleotides 322-360 of the cloned preproenkephalin (PPE) cDNA (Howells et al., 1984), nucleotides 1286-1333 of feline glutamic acid decarboxylase cDNA (GAD67; Kobayashi et al., 1987), nucleotides 767-803 of the dopamine D1 receptor cDNA (Monsma et al., 1990), and nucleotides 1587-1629 of an orphan opiate receptor cDNA (Wang et al., 1994). Oligonucleotides $(0.2 \mu \mathrm{M})$ were labeled at the $3^{\prime}$ end with $4 \mu \mathrm{M}$ $\left[\alpha-{ }^{35}\right.$ S $]$ dATP $(>37 \mathrm{TBq} / \mathrm{mmol}$; Amersham Pharmacia Biotech) using 15 $\mathrm{U}$ of terminal deoxynucleotidyltransferase (Amersham Pharmacia Biotech) for $2 \mathrm{hr}$ at $37^{\circ} \mathrm{C}$. The labeled probes were purified by spin-column chromatography (Chroma Spin Columns, Clontech Laboratories, Palo Alto, CA) to specific activities of $>10^{9} \mathrm{cpm} / \mu \mathrm{g}$. Specificity of the oligomers used had previously been determined by Northern blot analysis, homology screens of the sequences in GenBank, and comparisons of the anatomical distribution of the hybridization signal with previous studies attempting to localize the same mRNA transcripts. Specificity of hybridization was determined by competition experiments in which the ${ }^{35} \mathrm{~S}$-labeled probe was diluted with an excess of either the same unlabeled oligonucleotide or an unlabeled unrelated oligonucleotide.
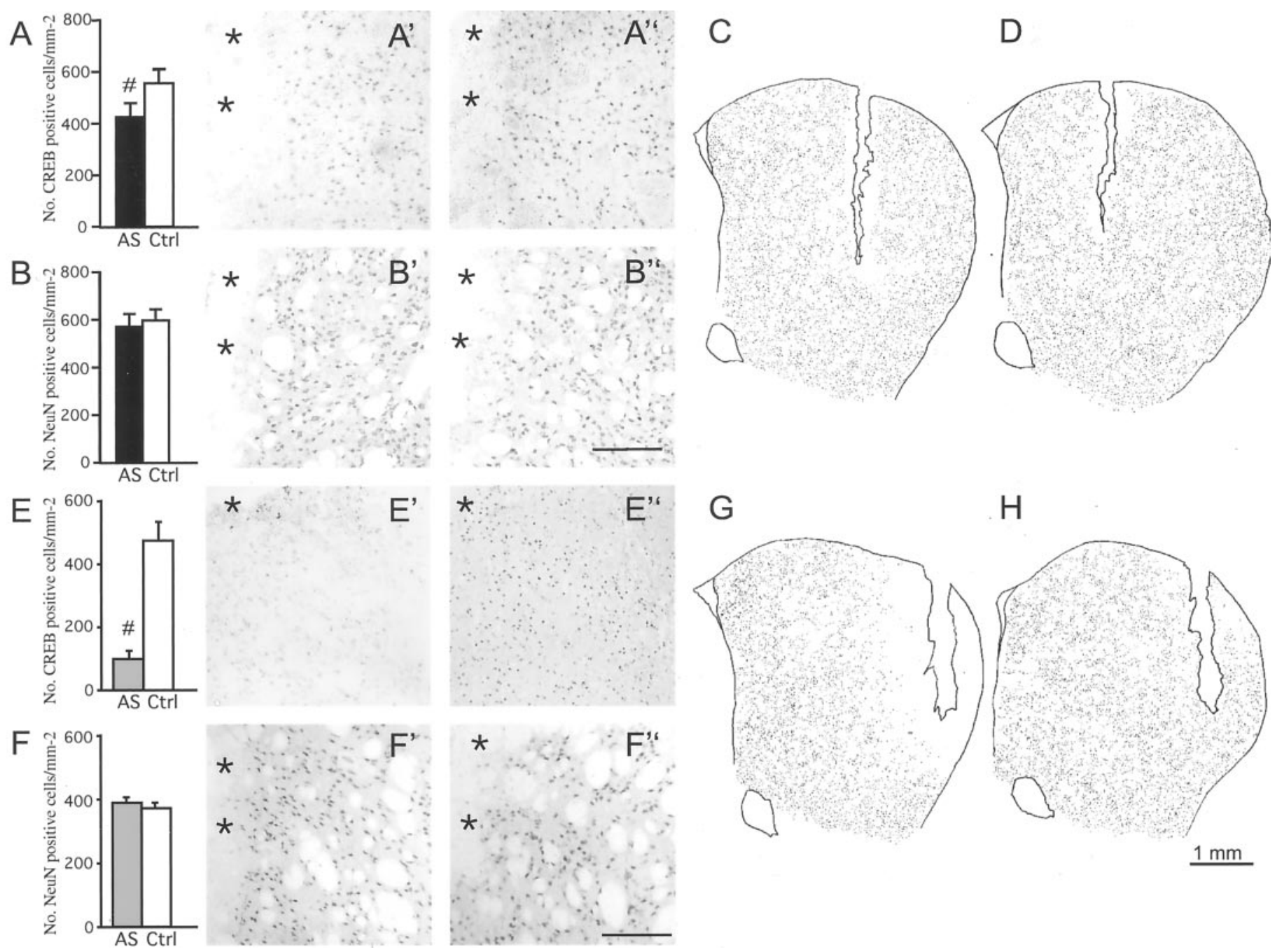

Figure 1. Different methods of CREB antisense delivery produce different extents of CREB knockdown in the striatum. The effects of single oligonucleotide injections are shown in $A-D$, whereas those produced by a $14 \mathrm{~d}$ oligonucleotide infusion are shown in $E-H$. The number of CREBimmunoreactive cells in the region flanking the injection cannula is shown in $A$ (single injection) or $E$ (continuous infusion), and the corresponding photomicrographs are shown in $A^{\prime}$ or $E^{\prime}$ (antisense group), and $A^{\prime \prime}$ or $E^{\prime \prime}$ (control oligonucleotide). NeuN-immunoreactive neurons within the same regions are shown in $B-B^{\prime \prime}$ and $F-F^{\prime \prime}$. Camera lucida drawings illustrate the regional distribution of CREB knockdown after single oligonucleotide injection $(C$, antisense; $D$, control) or continuous oligonucleotide infusion ( $G$, antisense; $H$, control). ${ }^{\#} p<0.01 ; n \geq 7$ in all groups; values give means + SEM. Asterisks in $A^{\prime}, A^{\prime \prime}, B^{\prime}, B^{\prime \prime}, E^{\prime}, E^{\prime \prime}, F^{\prime}$, and $F^{\prime \prime}$ mark the cannula track. $A S$, CREB antisense; $C t r l$, control oligo. Scale bars in $B^{\prime \prime}$ and $F^{\prime \prime}, 200 \mu \mathrm{m}$. 
The slide-mounted sections were air dried and incubated with the hybridization mixture, which comprised $50 \%$ formamide (deionized), $4 \times$ $\mathrm{SSC}(1 \times \mathrm{SSC}=0.15 \mathrm{M} \mathrm{NaCl}$ and $0.015 \mathrm{M}$ sodium citrate $), 1 \times$ Denhardt's solution $(0.02 \%$ Ficoll, $0.02 \%$ polyvinyl pyrolidone, $10 \mathrm{mg} / \mathrm{ml}$ of RNasefree bovine serum albumin), $1 \%$ sarcosyl, $10 \%$ dextran sulfate, $500 \mu \mathrm{g} / \mathrm{ml}$ sheared and denatured salmon sperm DNA, $25 \mu \mathrm{l} / \mathrm{ml}$ tRNA, $200 \mathrm{~mm}$ dithiothreitol, $0.2 \mathrm{mg} / \mathrm{ml}$ heparin, and $10^{7} \mathrm{cpm} / \mathrm{ml}$ of ${ }^{35} \mathrm{~S}$-labeled oligonucleotide probe. Forty microliters of hybridization mixture were added to each section $(240 \mu \mathrm{l}$ per slide). Slides were coverslipped with Parafilm and incubated for $18 \mathrm{hr}$ at $42^{\circ} \mathrm{C}$ in a humid chamber. After hybridization, the Parafilm coverslips were floated off in $1 \times \mathrm{SSC}$ at $55^{\circ} \mathrm{C}$, and the sections were given four $15 \mathrm{~min}$ washes in $1 \times \mathrm{SSC}$ at $55^{\circ} \mathrm{C}$, plus a final wash beginning at $55^{\circ} \mathrm{C}$; they were then cooled down to room temperature. The slides were then rinsed twice in distilled water, dehydrated in 70 and $95 \%$ ethanol ( $2 \mathrm{~min}$ each). The slides were exposed to Fuji imaging plates (see below) and subsequently dipped in photographic emulsion (LM-1, Amersham Pharmacia Biotech). Emulsion-coated sections were exposed for $2-7$ weeks at $-20^{\circ} \mathrm{C}$, developed in Kodak D-19 at $18^{\circ} \mathrm{C}$, fixed, and coverslipped with D.P.X. mountant (BDH).

Image analysis and cell counts. Quantitative analyses of ISHH or immunohistochemical specimens were performed by an investigator who was completely unaware of the rat group membership (experimentally blinded). An analysis of the antisense effect on various cellular markers was performed on two striatal sections per animal spanning rostrocaudal levels -0.2 to $+0.70 \mathrm{~mm}$ relative to bregma, according to Paxinos and
Watson (1997). Measurements were performed in two 0.54- $\mathrm{mm}^{2}$-large rectangular areas flanking the cannula track. Additional measurements were taken in control areas, having the same coordinates, on the contralateral side.

To measure ISHH labeling, the hybridized sections were exposed to Fuji imaging plates (Fujifilm Sweden AB) for 1-12 hr. The plates were scanned in a BAS-5000 phosphorimager (Fujifilm Sweden AB) to obtain digitized autoradiographs. The photo-stimulated luminescence emitted by the hybridized sections was calibrated against radioactivity levels (kilobecquerels per gram) using simultaneously exposed ${ }^{14} \mathrm{C}$ standards (Amersham Pharmacia Biotech). The hybridization signal was analyzed using the program TINA (Fujifilm Sweden AB).

Counts of immunostained cells were performed using the program NIH Image 1.61. Sample areas $\left(0.54 \mathrm{~mm}^{2}\right.$ in size) were digitized through a ProgRes3012 video camera (Kontron) connected to an Olympus microscope $(20 \times$ magnification). Data are expressed as number of positive cells per square millimeters.

Electrophoretic mobility shift assay. Anesthetized rats were killed by decapitation; the brains were rapidly extracted and immediately frozen on dry ice. Striata were dissected at $-20^{\circ} \mathrm{C}$ in a cryostat, and left and right striata were collected separately. Whole-cell protein extracts were prepared by Dounce homogenization in ice-cold homogenization buffer (20 $\mathrm{ll} / \mathrm{mg}$ tissue; $20 \mathrm{~mm}$ HEPES, $25 \%$ glycerol, $1.5 \mathrm{~mm} \mathrm{MgCl}_{2}, 0.4 \mathrm{~mm}$ EDTA, $1 \mathrm{~mm}$ DTT, $0.5 \mathrm{mM}$ PMSF). The homogenate was centrifuged at $10,000 \mathrm{x} g$ for $3 \mathrm{~min}$ at $4^{\circ} \mathrm{C}$. The preparation was homogenized once more
A

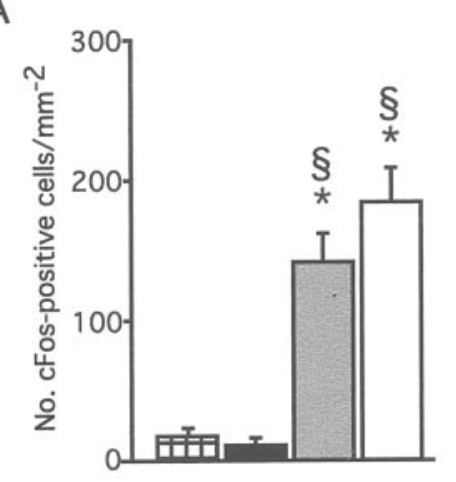

D

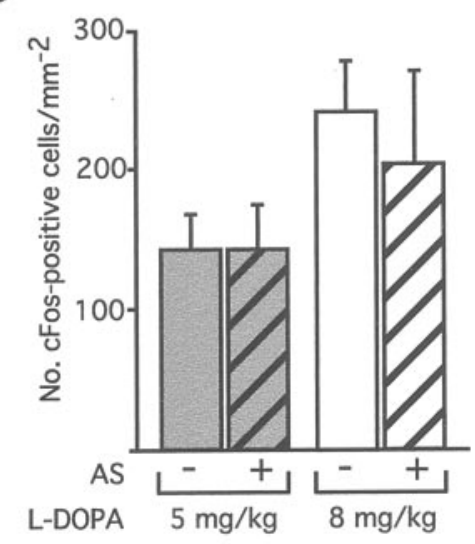

B

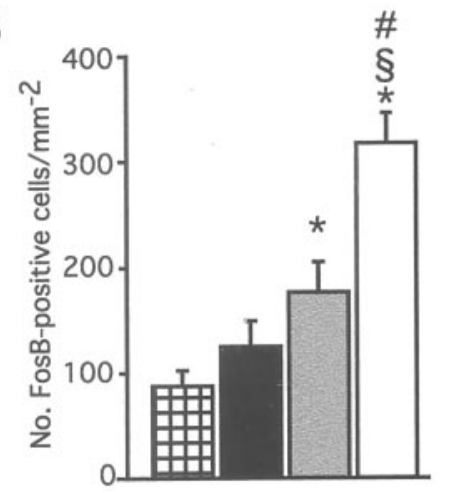

E

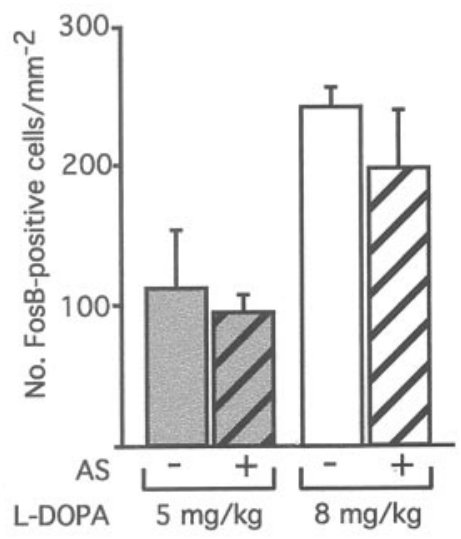

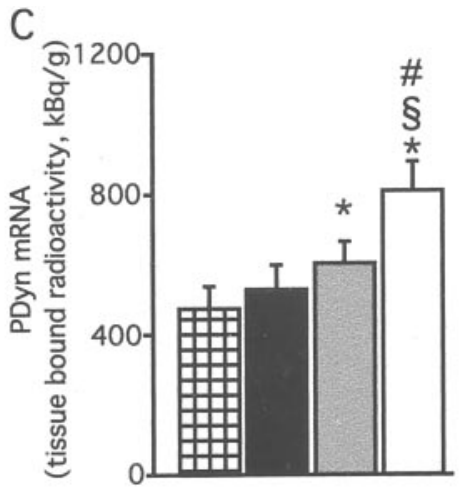

$\mathrm{F}$

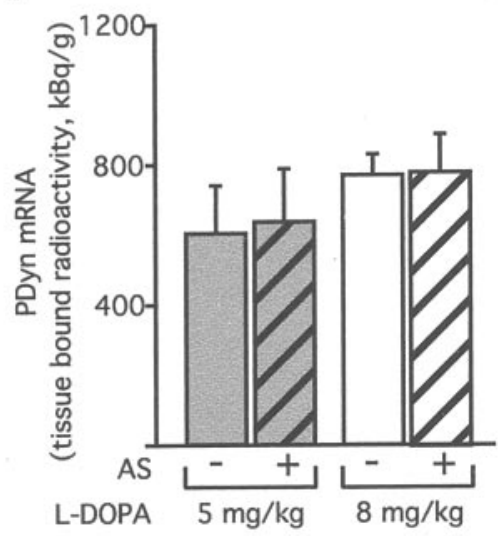

lesion-only

L-DOPA, $3 \mathrm{mg} / \mathrm{kg}$

L-DOPA, $5 \mathrm{mg} / \mathrm{kg}$

L-DOPA, 8 mg/kg

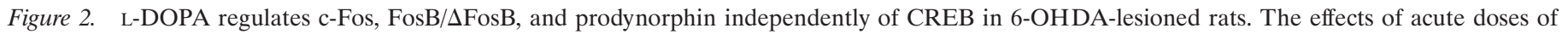

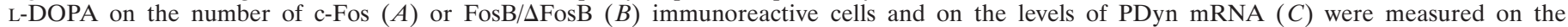

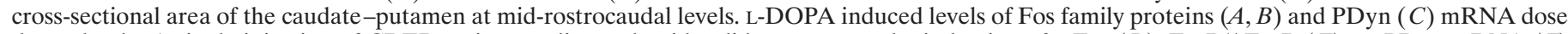

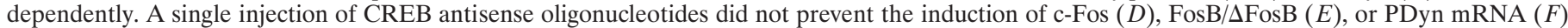

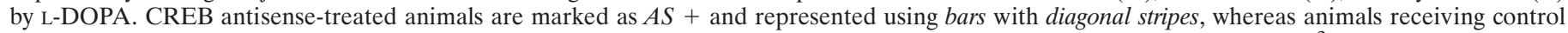

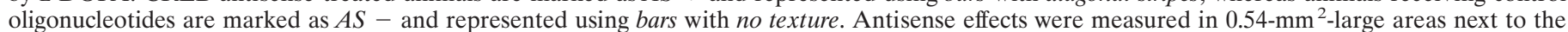

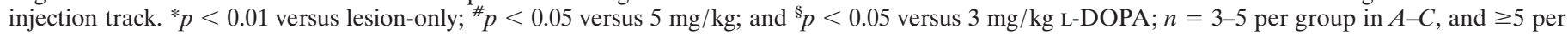
group in $D-F$; values give means + SEM. 
and centrifuged at $10,000 \times \mathrm{g}$ for $10 \mathrm{~min}$ at $4^{\circ} \mathrm{C}$. The supernatant was collected and protein concentration was determined using the Bio-Rad Protein Assay (Bio-Rad Laboratories, Hercules, CA).

Oligonucleotides were synthesized with two G-overhangs and annealed in the presence of $20 \mathrm{~mm} \mathrm{NaPO}_{4}, 1 \mathrm{~mm}$ EDTA, and $100 \mathrm{~mm} \mathrm{KCl}$. Double-stranded oligonucleotides were radioactively labeled with ${ }^{32} \mathrm{P}$-dCTP by reverse transcription (Moloney murine leukemia virus reverse transcriptase, Promega, Madison, WI). The dynCRE3 used (nucleotides -1562 to -1522 of the rat PDyn promoter; $5^{\prime}$-CCTGCTGCGTCAGAGCATGA-3') (Douglass et al., 1994) has been shown to be important for CREB-regulated PDyn gene expression in various cell culture systems (Collins-Hicok et al., 1994; Messersmith et al., 1994). The dynAP-1 element is a noncanonical AP-1 site mapping to oligonucleotides -257 to -249 of the PDyn promoter (5'-TTTGAAGTGACAAACAGCGCT-3') (Naranjo et al., 1991). Two additional sequences were used for comparison, namely, the consensus sequence for the palindromic CRE/ATF site, here called consensus CRE (Konradi et al., 1993)(5'-GCTGACGTCAGGG-3'), and a canonical AP-1 sequence from the human collagenase promoter (5'-TTCCGGCTGACTCATCAAGCG-3') (Vallone et al., 1997).

To examine DNA-protein interactions, protein extracts $(3 \mu \mathrm{g})$ were preincubated on ice for $10 \mathrm{~min}$ in gel-shift buffer (10 mM HEPES, $10 \%$ glycerol, $0.1 \mathrm{~mm}$ EDTA, $67 \mathrm{~mm} \mathrm{KCl}, 150 \mathrm{ng}$ poly(dI-dC), $5 \mathrm{~mm} \mathrm{MgCl}_{2}$, $2 \mathrm{~mm}$ DTT, and $100 \mathrm{~mm}$ PMSF). After preincubation, $1 \mathrm{ng}$ of ${ }^{32} \mathrm{P}$-labeled double-stranded oligonucleotide was added, and the samples were incubated for $10 \mathrm{~min}$ at room temperature. DNA-protein complexes were separated on a $4 \%$ nondenaturing polyacrylamide gel (29.5:1 acrylamide/ bisacrylamide $)$ in $0.25 \times$ TBE buffer $(1 \times$ TBE contains 0.0045 M Trisborate and $0.002 \mathrm{~m}$ EDTA). The gel was dried onto a filter paper and exposed to autoradiographic films or phosphorimager plates (Fujifilm Sweden AB) that were later used for computer-assisted measurements of the optical density of shifted bands.

Cold competition assays were performed using two different mixes of protein extracts, pooled from the striatum either ipsilateral (lesioned side) or contralateral (intact side) to the 6-OHDA lesion of three chronically L-DOPA-treated rats. Samples of $3 \mu \mathrm{g}$ of pooled protein extracts were incubated with nonradioactively labeled consensus CRE or canonical AP- 1 oligonucleotides at $5 \times$ and $50 \times$ the concentration of the radioactively labeled probe.

In supershift assays, the preincubation was extended in the presence of antisera overnight, and proteinase inhibitors were added $[500 \mu \mathrm{M}$ 4-(2-aminoethyl)-benzenesulfonylfluoride, $150 \mathrm{nM}$ aprotinin, $1 \mu \mathrm{M}$ leupeptin, $0.5 \mathrm{~mm}$ EDTA, $1 \mu \mathrm{M}$ E-64; Proteinase Inhibitor Cocktail Set I, Calbiochem].

Western immunoblotting. Striatal protein extracts were prepared as described above. Proteins $(7.5 \mu \mathrm{g})$ were loaded onto a $12 \%$ acrylamide resolving gel $/ 4 \%$ stacking gel for SDS-PAGE and electroblotted onto polyvinylidene difluoride membranes (Amersham Pharmacia Biotech). Membranes were blocked in TBS-T (20 mM Tris, $\mathrm{pH} 7.6,0.9 \% \mathrm{NaCl}$, $0.01 \%$ Tween 20 ) containing $3 \%$ non-fat dry milk and then incubated overnight at $4^{\circ} \mathrm{C}$ with antiserum. After four $15 \mathrm{~min}$ rinses in TBS-T, membranes were incubated with horseradish peroxidase-conjugated antirabbit antibodies (Amersham Pharmacia Biotech; 1:2000 in TBS-T) for 1 $\mathrm{hr}$ at room temperature. The membranes were washed four times for 15 min each in TBS-T and developed with the enhanced chemoluminescence method (ECL; Amersham Pharmacia Biotech), and exposed to Hyperfilm-ECL (Amersham Pharmacia Biotech) for 5-45 min. The following antisera were used at the indicated dilutions: FosB/ $\Delta$ FosB (1:10 000, rabbit polyclonal from Santa Cruz Biotechnology), FosB/
$\Delta$ FosB (1:7500, rabbit polyclonal from Research Biochemicals International, Natick, MA), and panFos (1:5000, kind gift of Dr. E. Vaudano, Lundbeck A/S).

Statistical analysis. Image-analysis data from antisense-treated and control rats were compared using Student's two-tailed $t$ test. Statistical comparisons between more than two groups were performed using one-factor ANOVA and post hoc Newman-Keuls test. Correlations were estimated using simple regression analysis. Group comparisons of dyskinesia and stereotypy rating scores were performed using the MannWhitney $U$ test. The null hypothesis was rejected when $p<0.05$.

\section{RESULTS}

\section{Regional specificity, time dependence, and dose dependence of antisense-mediated CREB knockdown}

In agreement with previous studies (Konradi et al., 1994; Konradi and Heckers, 1995), we found that a single antisense injection produced a downregulation of striatal CREB immunoreactivity, which was maximal at $\sim 32 \mathrm{hr}$ after injection. At this time, a single dose of CREB antisense $(2.5 \mathrm{nmol})$ had reduced the number of CREB-immunoreactive neurons by $23.4 \pm 9.5 \%$ in a region extending up to $300 \mu \mathrm{m}$ around the injection site $(p<0.01 \mathrm{vs}$ control group) (Fig. $\left.1 A-A^{\prime \prime}, C\right)$. By comparison, the number of cells immunoreactive for the neuron-specific marker NeuN was the same in the AS and control (Ctrl) groups (Fig. $\left.1 B-B^{\prime \prime}\right)$.

Continuous infusion of CREB antisense over $14 \mathrm{~d}(2.5 \mathrm{nmol} / \mathrm{d})$ produced a dramatic downregulation of CREB-immunoreactive cell numbers $\left(-80 \pm 5 \%\right.$ vs $C$ trl group) (Fig $\left.1 E-E^{\prime \prime}\right)$. The knockdown of CREB was still evident at $1 \mathrm{~mm}$ distance from the cannula (compare AS with $\mathrm{Ctrl}$ in Fig. $1, G$ and $H$, respectively). The antisense effect was not caused by unspecific cell death, because there was no difference in the number of NeuNimmunoreactive neurons between the AS and Ctrl groups (Fig. $\left.1 F-F^{\prime \prime}\right)$. In addition, the expression of constitutively expressed transcription factors (JunD) or mRNA transcripts (PPE, GAD, D1-receptor, and an orphan opiate receptor mRNA) did not differ between the two groups $(p>0.27$ in AS vs Ctrl oligo group; data not shown). Moreover, using Fluoro-Jade B histofluorescence as a method to detect degenerating neurons (Schmued and Hopkins, 2000), we did not find ongoing cell death in the region adjoining the chronic oligonucleotide infusion, although we saw a number of fluorescent neurons after acute oligonucleotide injections (data not shown).

\section{CREB is not required for L-DOPA-induced changes in C-fos, fosB, and prodynorphin gene expression in the DA-denervated striatum}

Before studying the effects of CREB antisense, we set out to determine whether single doses of L-DOPA, which lie within the therapeutic range for the treatment of Parkinson's disease $(3,5$,

Table 2. Continuous CREB antisense infusion does not affect L-DOPA-induced changes in gene expression

\begin{tabular}{lccccc} 
& \multicolumn{2}{c}{ Acute L-DOPA } & & \multicolumn{2}{c}{ Chronic L-DOPA } \\
\cline { 2 - 3 } \cline { 5 - 6 } Gene expression markers & CREB AS & Control oligo & & CREB AS & Control oligo \\
\hline Number of c-Fos + cells & $144 \pm 31$ & $106 \pm 31$ & & $9 \pm 4$ & $8 \pm 3$ \\
Number of FosB + cells & $42 \pm 9$ & $63 \pm 18$ & & $140 \pm 32$ & $170 \pm 62$ \\
PDyn mRNA $(\mathrm{kBq} / \mathrm{gm})$ & $976 \pm 89$ & $1061 \pm 71$ & & $2250 \pm 325$ & $1881 \pm 541$ \\
\hline
\end{tabular}

Data were collected from animals sustaining continuous oligonucleotide inf usion in the lateral caudate-putamen for $14 \mathrm{~d}$. L-DOPA $(8 \mathrm{mg} / \mathrm{kg}$ per injection, i.p) was administered either on day 14 (acute treatment) or on days 2-14 (chronic treatment). The three genes under investigation show a differential response to the effects of chronic versus acute L-DOPA treatment: higher levels of PDyn mRNA and FosB-like proteins are seen after chronic treatment, and higher levels of c-Fos expression are found after acute treatment. However, none of the observed changes is affected by CREB antisense. 

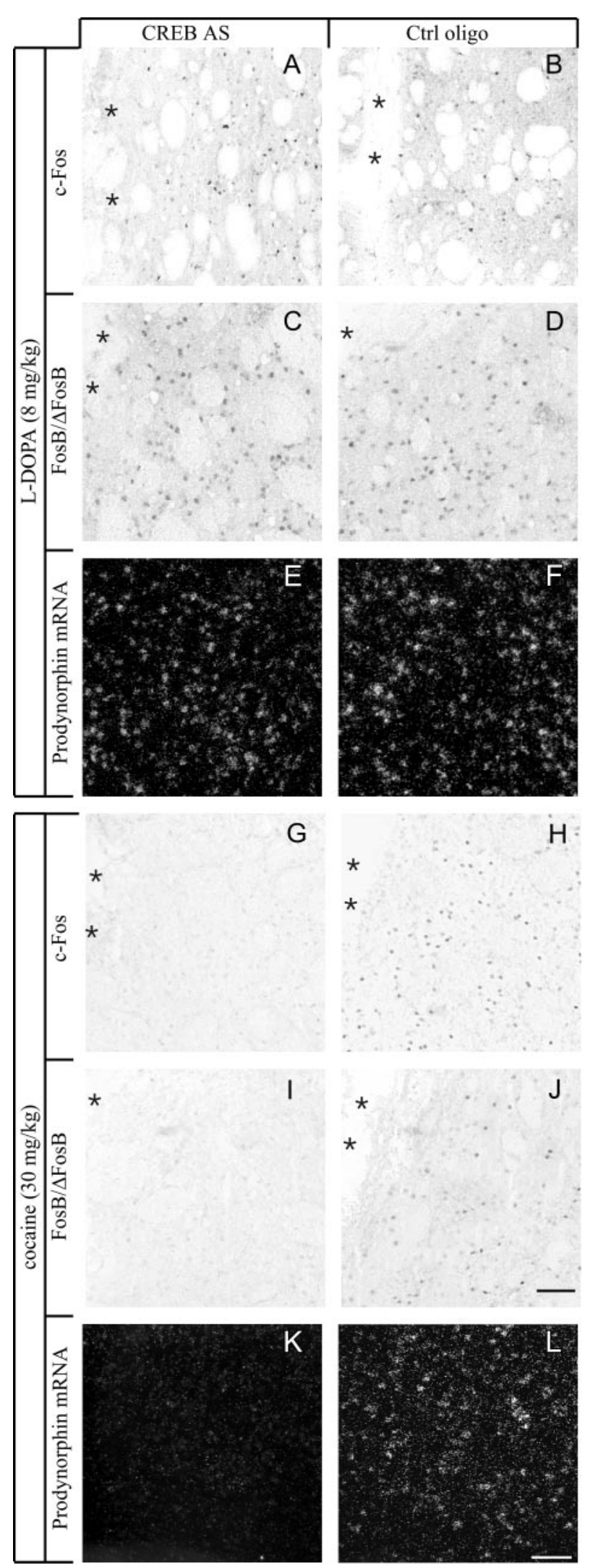

Figure 3. CREB knockdown differentially affects the induction of c-Fos $(A, B, G, H), \mathrm{FosB} / \Delta \mathrm{FosB}(C, D, I, J)$, or PDyn mRNA $(E, F, K, L)$ by L-DOPA or cocaine. In the absence of CREB, L-DOPA was able to induce all gene expression markers in the 6-OHDA-lesioned striatum (compare antisense group in $A, C$, and $E$ with control group in $B, D$, and $F$ ), whereas
A Acute L-DOPA B Chronic L-DOPA
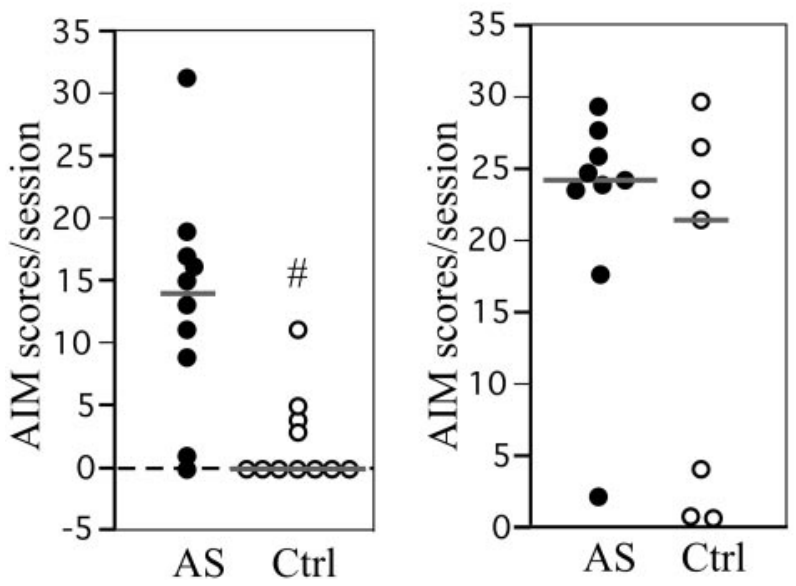

Figure 4. Loss of CREB increases abnormal involuntary movements (orolingual, limb, and axial AIMs) in 6-OHDA-lesioned rats treated with L-DOPA. In the acutely L-DOPA-treated rats $(A)$, CREB antisense produced levels of AIM scores that were similar to chronic L-DOPA-treated rats (compare $A S$ group in $A$ with $C t r l$ group in $B$ ). A trend toward more severe dyskinesias in the CREB AS group was also seen during chronic L-DOPA treatment $(B)$. AIMs scores were collected during a single testing session in $A$ and during four testing sessions in $B$ (the AIM score in the last of these sessions is shown in the diagram). Each dot in the scattergram represents one single animal; the group median is shown as a horizontal bar. ${ }^{\#} p<0.01$.

and $8 \mathrm{mg} / \mathrm{kg}$ ), were sufficient to induce changes in the expression of the genes under investigation. Drug-induced expression of $c$-fos and fos $\mathrm{B}$ was monitored at the protein rather than mRNA level because the interval after injection that was chosen in this study $(3 \mathrm{hr})$ is beyond the peak of mRNA induction.

L-DOPA was found to induce c-Fos, FosB/ $\Delta$ FosB, and PDyn mRNA expression in the DA-denervated striatum in a dosedependent manner (Fig. $2 A-C$ ). Doses of 5 and $8 \mathrm{mg} / \mathrm{kg}$ L-DOPA induced a significant increase in c-Fos and FosB $/ \Delta$ FosB immunoreactivity (Fig. $2 A, B$ ), as well as in PDyn mRNA levels (Fig. $2 C$ ), whereas the lowest dose tested did not produce any detectable effects.

Surprisingly, a single injection of CREB antisense had no effect on the ability of either 5 or $8 \mathrm{mg} / \mathrm{kg}$ L-DOPA to induce c-Fos, FosB/ $\Delta$ FosB, or PDyn in striatal neurons (Fig. $2 D-F$ ). We therefore asked whether a more pronounced downregulation of CREB would be required to block the effects of L-DOPA. CREB antisense was continuously infused into the DA-denervated striatum for $14 \mathrm{~d}$, during which time the rats received either acute (on day 14 ) or chronic treatment (on days $2-14$ ) with L-DOPA $(8 \mathrm{mg} / \mathrm{kg}$ per injection). Continuous CREB antisense infusion neither blocked nor attenuated the effects of acute or chronic L-DOPA treatment on striatal gene expression (Table 2, Fig. $3 A-F$ ).

Behavioral testing showed that continuous CREB antisense infusion exacerbated the dyskinetic effects of L-DOPA (Fig. 4). After intrastriatal CREB knockdown, acute L-DOPA injections

cocaine was unable to induce the same gene products in the intact striatum $(G, I, K$, antisense group; $H, J, L$, control group). Photomicrographs were taken under bright-field $(A-D, G-J)$ or dark-field illumination $(E, F, K, L)$ from animals that sustained intrastriatal oligonucleotide infusion and acute drug injections. Asterisks mark the cannula track. Scale bar, $100 \mu \mathrm{m}$. 

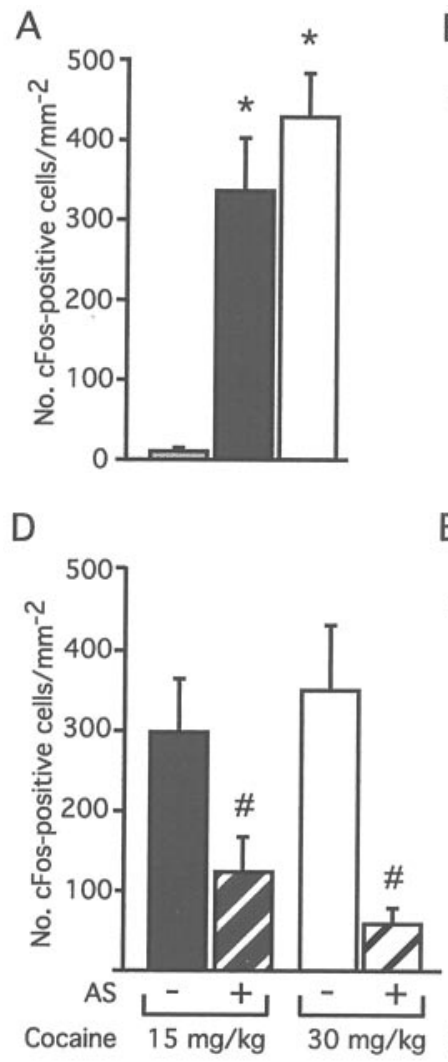

B

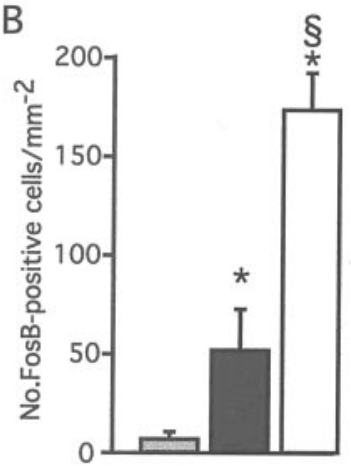

$\mathrm{E}$

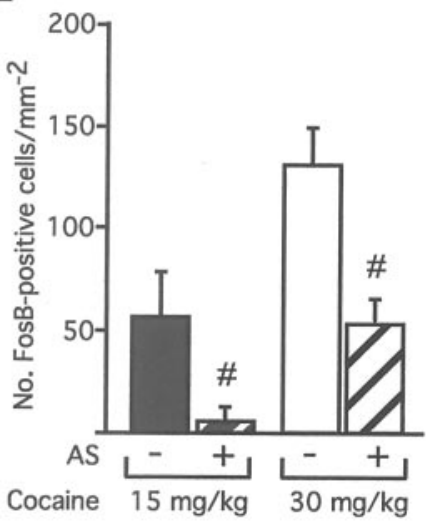

$\mathrm{C}$

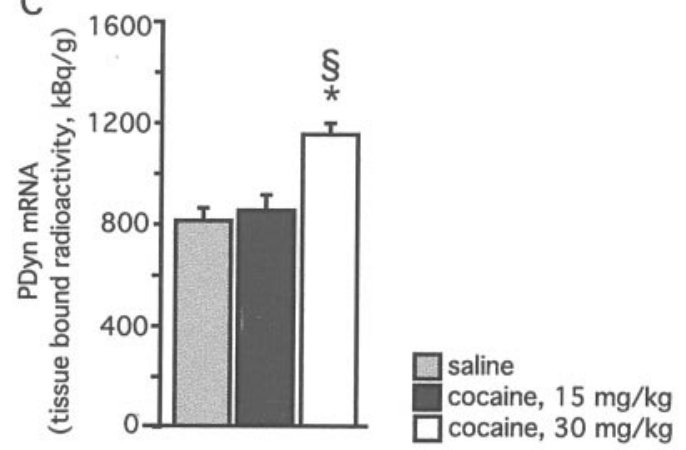

F

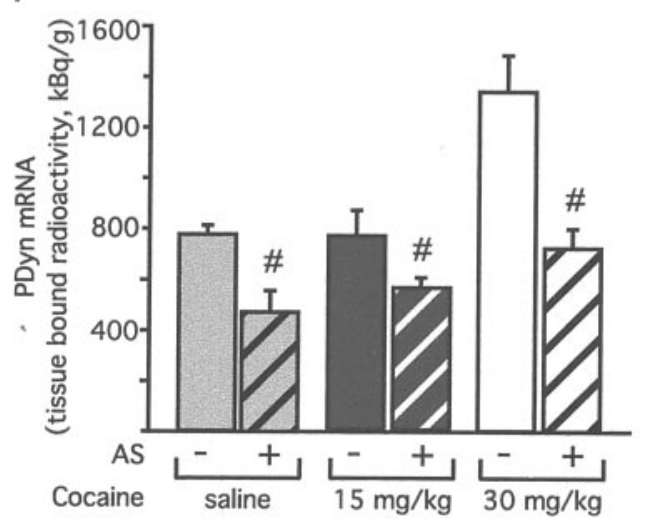

Figure 5. Cocaine-induced expression of c-Fos, FosB/ $\mathrm{FFosB}$, and PDyn mRNA is dependent on CREB. Acute treatment with cocaine produced a dose-dependent increase in the number of c-Fos $(A)$ and FosB/ $\Delta$ FosB immunoreactive cells $(B)$, and in the levels of PDyn mRNA $(C)$, as measured on the cross-sectional area of the caudate-putamen at mid-rostrocaudal levels. Knockdown of CREB prevented the cocaine-stimulated increase in c-Fos $(D), \operatorname{FosB} / \Delta$ FosB $(E)$, and PDyn mRNA $(F)$. CREB antisense-treated animals are marked as $A S+$ and represented using bars with diagonal stripes, whereas animals receiving control oligonucleotides are marked as $A S$ - and represented using bars with no texture. The data presented here are derived from two sets of experiments. Animals injected with $15 \mathrm{mg} / \mathrm{kg}$ cocaine received a single intrastriatal injection of CREB AS, whereas animals injected with $30 \mathrm{mg} / \mathrm{kg}$ cocaine or saline received a $14 \mathrm{~d}$ intrastriatal oligonucleotide infusion. ${ }^{*} p<0.05$ versus saline; ${ }^{\circledR} p<0.01 \mathrm{versus} 15 \mathrm{mg} / \mathrm{kg}$ cocaine; ${ }^{\#} p<$ 0.05 versus control oligo; $n \geq 5$ in each group; values give means + SEM.

produced severe AIMs of the trunk, limb, and orofacial region, i.e., body parts that are somatotopically related to the lateral striatal subregion targeted by the antisense $(p=0.003$ in AS vs Ctrl group) (Fig. 4A). A trend toward more severe dyskinesias after CREB AS inf usion was also seen when L-DOPA was given chronically on days 2-14 after pump implantation (but $p=0.112$ ) (Fig. $4 B$ ). Thus, in contrast with our initial hypothesis and that of others (Calon et al., 2000), these data demonstrate that CREB is not required for the development of dyskinesia and that its knockdown causes greater sensitivity to the dyskinesiogenic effects of L-DOPA.

\section{CREB is essential for both basal and cocaine-induced c-fos, fosB, and prodynorphin gene expression in the intact striatum}

The failure of CREB antisense to block gene expression changes produced by L-DOPA was not compatible with the proposed critical role of CREB in DA-dependent nuclear signaling. This prompted us to examine the requirement for CREB as a mediator of DA-dependent gene expression in the intact striatum using our knockdown paradigm. Previous studies had shown that CREB antisense could block amphetamine-induced striatal c-Fos expression in normal rats (Konradi et al., 1996). However, no data were available on the role of CREB in PDyn and fos $\mathrm{B}$ gene induction by DA agonists in the striatum in vivo.

A single, intrastriatal injection of CREB AS oligonucleotides attenuated the inductive effect of $15 \mathrm{mg} / \mathrm{kg}$ cocaine on c-Fos and FosB $/ \Delta$ FosB immunoreactivity (Fig. $5 A, B, D, E$ ) and caused a $\sim 40 \%$ reduction in PDyn mRNA levels within the targeted striatal subregion (Fig. $5 F$ ). The latter effect represents a downregulation of basal PDyn gene expression, because $15 \mathrm{mg} / \mathrm{kg}$ cocaine did not have a significant inductive effect on the PDyn transcript [Fig. 5C (compare black and shaded bars)]. We thus tested a higher dose of cocaine $(30 \mathrm{mg} / \mathrm{kg}$, i.p.), which produced a marked induction of all the genes under investigation (Fig. $5 A-C$, white bars $)$. In this experiment, CREB AS oligonucleotides were delivered chronically into the striatum for $14 \mathrm{~d}$ using osmotic minipumps. c-Fos, FosB/ $\Delta$ FosB, and PDyn mRNA induction by $30 \mathrm{mg} / \mathrm{kg}$ cocaine was completely blocked by CREB AS inf usion (Fig. 5D-F; photomicrographs are shown in Fig. 3G-L). An analysis of animals injected with saline instead of cocaine on the 14th day of antisense infusion confirmed that CREB was required to maintain basal expression of PDyn mRNA in the striatum (Fig. $5 F$, shaded bars).

Behavioral testing showed that CREB AS inf usion significantly enhanced the activity/stereotypy scores recorded from control animals injected with saline (Fig. 6A) ( $p=0.020$ for $A S$ vs $C t r l)$. On single monitoring periods, CREB AS rats reached scores of 2 , whereas the highest scores recorded from control rats never exceeded 1 [note that scores of 1-2 in the Creese and Iversen (1973) scale indicate motor activation rather than stereotypy; see 
A Saline

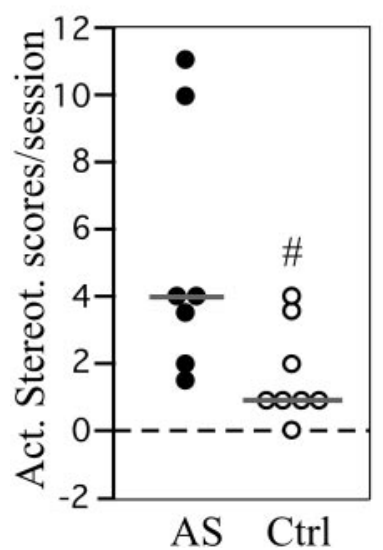

B Cocaine

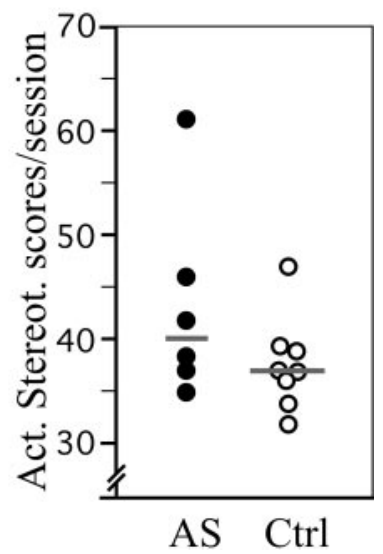

Figure 6. Loss of CREB increases activity/stereotypy scores in intact rats challenged with an injection of saline $(A)$ but not cocaine $(B)$. CREB AS was infused continuously for $14 \mathrm{~d}$ before the acute challenge. The rats were neurologically intact. Each dot in the scattergram represents one single animal; the group median is shown as a horizontal bar. ${ }^{*} p<0.01$.

Materials and Methods]. CREB AS, however, did not produce a significant effect on cocaine-induced stereotypies (Fig. 6B) $(p=$ 0.243 ; maximal stereotypy scores per monitoring period amounted to 4-5 in CREB AS rats and 3-4 in the controls).

\section{DNA binding activity in the DA-denervated striatum: effects of L-DOPA treatment}

In agreement with previous studies (Cole et al., 1995; Carlezon et al., 1998), our antisense data showed that the PDyn gene is an important target of CREB in the intact striatum, but indicated that transcription factors other than CREB regulate PDyn expression in the parkinsonian striatum treated with L-DOPA. We were therefore interested in studying striatal DNA binding activity at two enhancer elements from the PDyn promoter: the noncanonical dynCRE3 element (Collins-Hicok et al., 1994; Douglass et al., 1994; Messersmith et al., 1994; Cole et al., 1995) and the noncanonical dynAP-1 (Naranjo et al., 1991). Both enhancer elements have been shown to mediate induction of PDyn in different cell culture systems. We compared binding at these two elements with binding at a consensus CRE (Konradi et al., 1993) and at a canonical AP-1 element (Vallone et al., 1997).

The specificity of DNA binding activity at dynCRE3 and dynAP-1 was verified by cold competition with nonradioactively labeled consensus CRE or canonical AP-1 oligonucleotides, using protein extracts prepared from both the DA-denervated and the intact striatum of L-DOPA-injected animals. The canonical AP-1 and consensus CRE oligonucleotides competed with both PDynenhancer elements in a dose-related manner (Fig. 7A,B). By contrast, an unrelated AP-4 oligonucleotide did not compete for but rather enhanced the specific dynCRE3 and dynAP-1 binding (Fig. 7).

In line with previous studies (Hope et al., 1994; Doucet et al., 1996; Kashihara et al., 1996), DA denervation alone produced a slight induction of DNA binding to the consensus AP-1 on the lesioned side (Fig. 8A). In addition, we found a small increase of binding to the dynCRE3 (Fig. $8 C$, compare lanes 1, 2).

Both acute and chronic L-DOPA treatment produced a further increase in binding of striatal proteins from the lesioned side to all the promoter elements tested, particularly to the dynCRE3 and the canonical AP-1 (Fig. 8A,C, compare L-DOPA, lanes 3

\section{A dynCRE3}

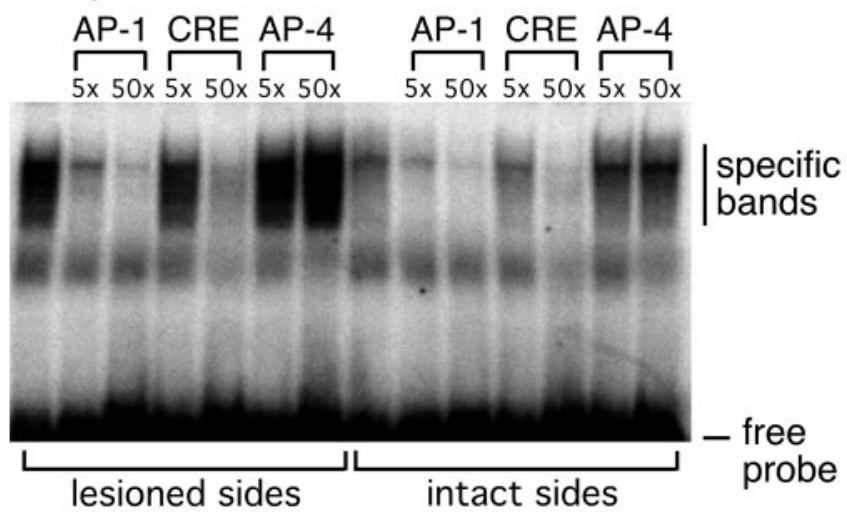

B dynAP-1

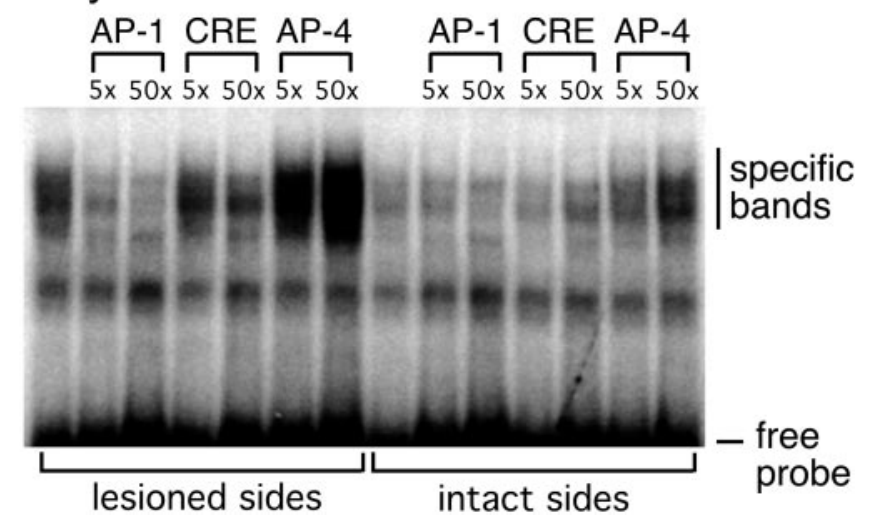

Figure 7. Gel mobility shift assay and competition experiment determine the specificity of DNA-protein complexes formed with dynCRE3 $(A)$ and dynAP-1 $(B)$. Unlabeled consensus AP-1, CRE, and the unrelated AP-4 sequences were used to compete for proteins bound to radiolabeled dynCRE3 $(A)$ and dynAP1 $(B)$ promoter elements. Striatal samples were pooled from several L-DOPA-treated rats. The experiment was repeated three times.

and 5, and saline, lane 1). The increase in DNA binding activity induced by chronic L-DOPA treatment was associated with the development of abnormal involuntary movements during the drug treatment period (Fig. 8B,D). Animals that did not develop dyskinesias showed levels of DNA binding activities comparable to those found in saline-injected (lesion-only) controls (Fig. $8 A, C$, compare nondyskinetic rat in lane 7 and dyskinetic rat in lane 5).

In addition, both acute and chronic L-DOPA treatment induced striatal DNA binding activity to the dynAP-1 (Fig. $8 E$ ) and to the consensus CRE probe (Fig. $8 F$ ).

\section{FosB-related proteins account for striatal CRE- and AP-1-binding activity in DA-denervated animals treated with L-DOPA}

Striatal protein extracts from DA-denervated and chronically L-DOPA-treated animals were incubated with antibodies against CREB or FosB/ $\Delta$ FosB-related antigens (before the addition of a radioactive oligonucleotide probe) to determine which of these proteins interacted with the enhancer elements under investigation. The FosB $/ \Delta$ FosB antibody was particularly interesting to test, because of previous findings in our lab demonstrating that 


\section{A canonical AP-1}

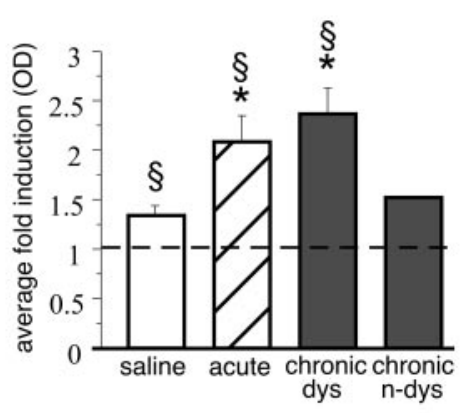

\section{C dynCRE3}

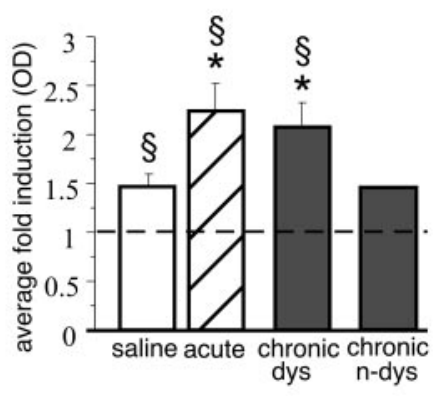

\section{E dynAP-1}

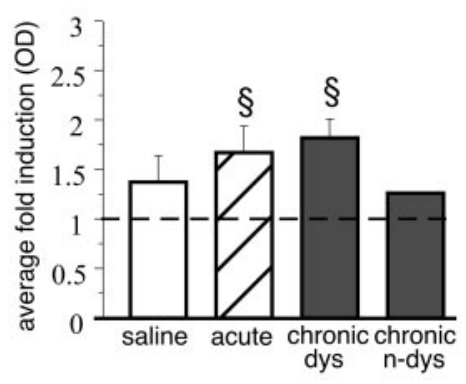

\section{F consensus CRE}

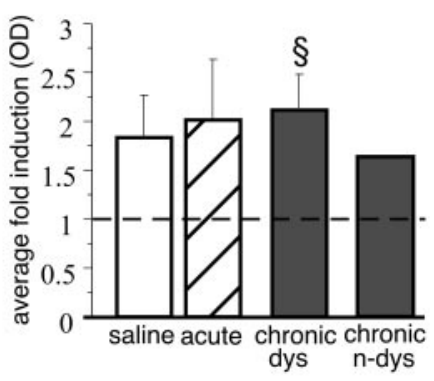

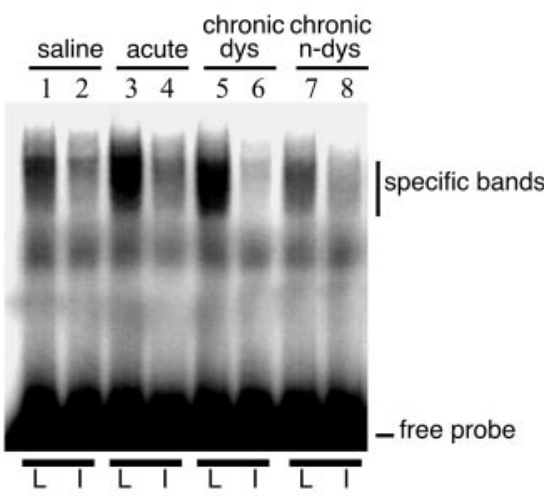

\section{B canonical AP-1}

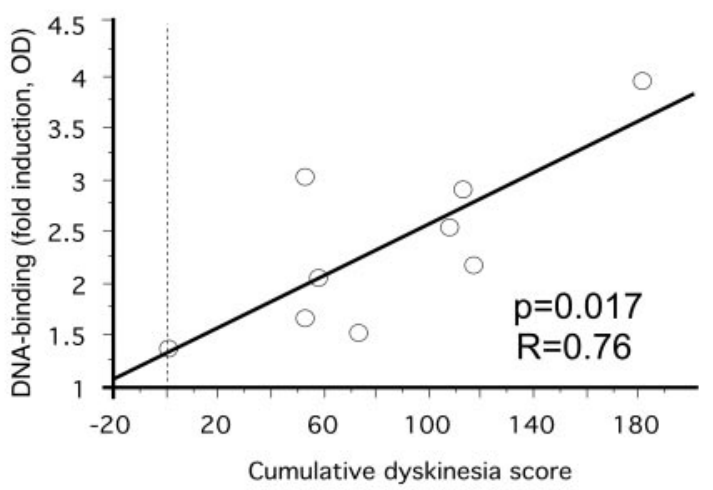

D dynCRE3
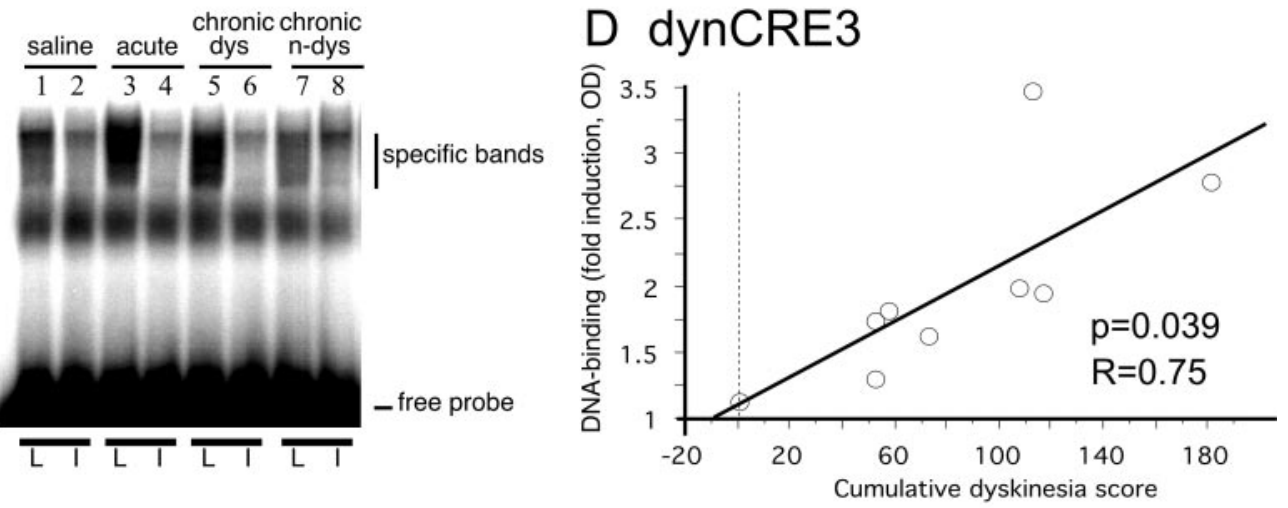
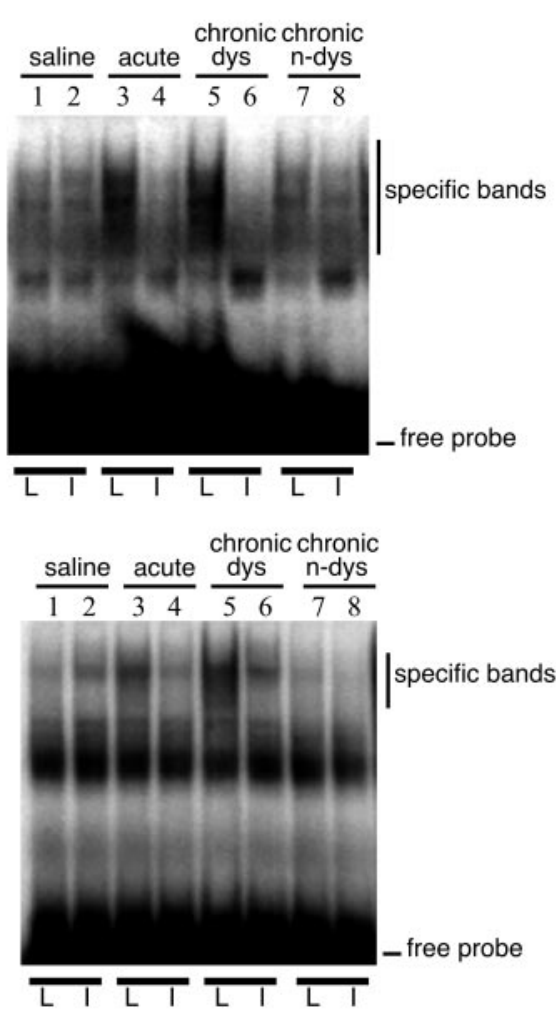

Figure 8. Acute and chronic treatment with L-DOPA induces striatal DNA binding activity to the canonical AP-1 $(A)$, the dynCRE3 $(C)$, the dynAP-1 $(E)$, and the consensus CRE $(F)$. Optical densities of specific bands are expressed as the fold induction on the lesioned over the intact side. ${ }^{*} p<0.05$ versus saline group; ${ }^{\S} p<0.05$ versus intact side; values give means + SEM; $n \geq 5$ in all groups but chronic $n$-dys (i.e., chronically L-DOPA-treated but nondyskinetic case). As shown in $B$ and $D$, only one animal remained nondyskinetic (0 cumulative dyskinesia scores) during chronic L-DOPA treatment. In $B$ and $D$, levels of binding to the canonical AP-1 $(B)$ and dynCRE3 $(D)$ in the chronic L-DOPA cases are plotted on the cumulative axial, limb, and orolingual AIM scores recorded from the same animals. The probability value $(p)$ and correlation coefficient $(R)$ of the corresponding simple regression

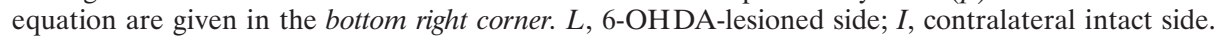



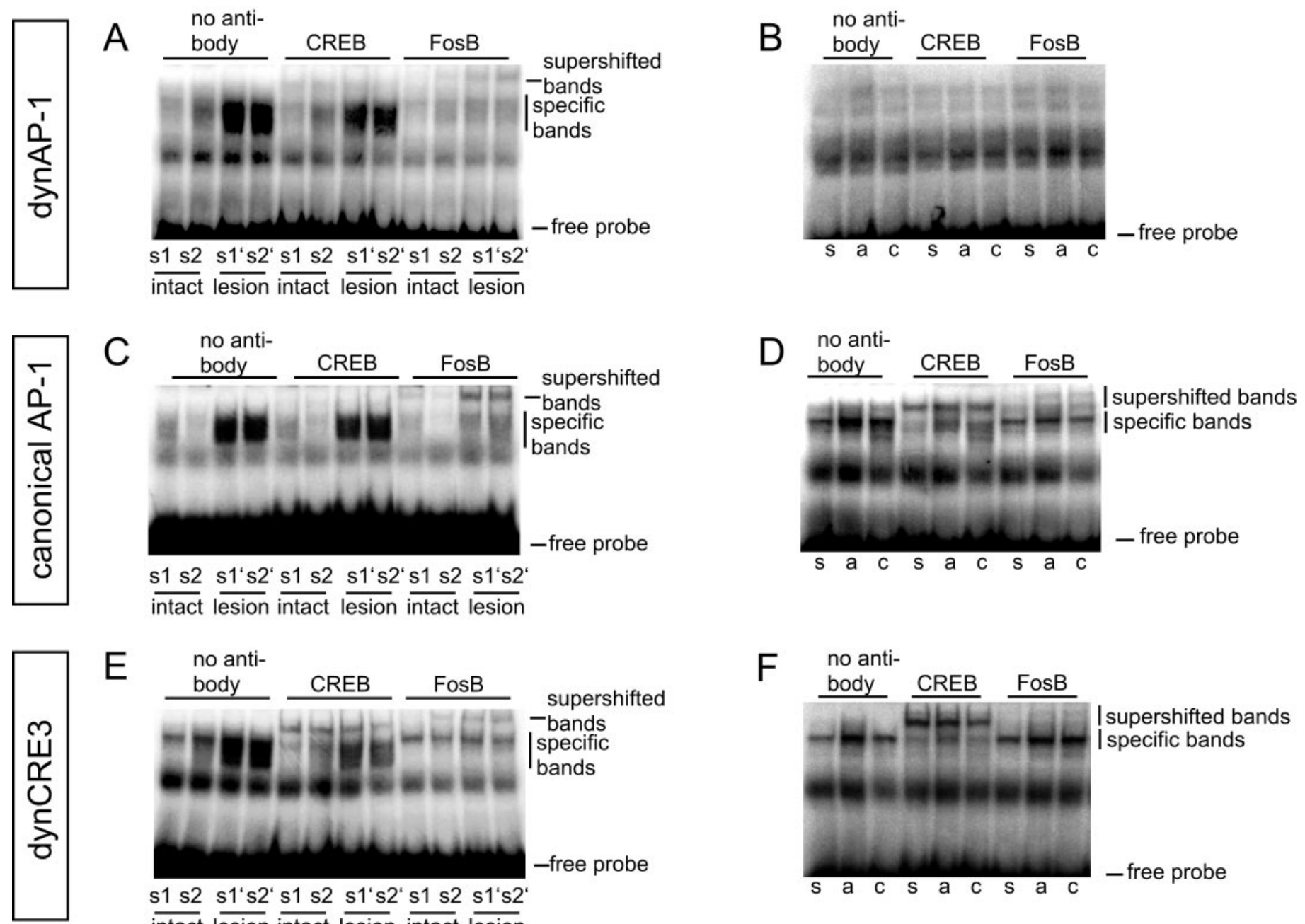

s1 s2 s1's2's1s2 s1's2's1 s2 s1's2'

$\overline{\text { intact lesion intact lesion intact lesion }}$
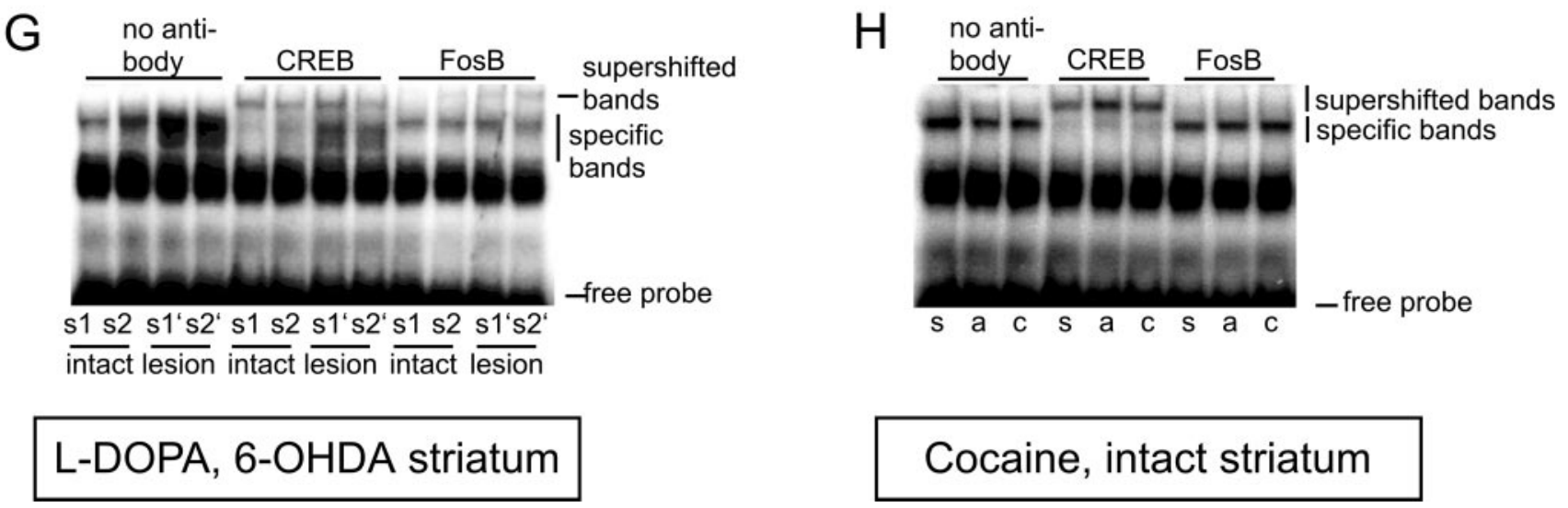

Cocaine, intact striatum

Figure 9. FosB/AFosB-related proteins are the predominant transcription factors bound to CRE and AP-1 enhancers in L-DOPA-treated rats. To study the contribution of CREB- or FosB/ $\Delta$ FosB-related proteins to the DNA binding activity induced by L-DOPA $(A, C, E, G)$ or cocaine $(B, D, F, H)$, supershift assays were performed using antisera against CREB or FosB/ $\Delta$ FosB. Antibodies were preincubated with striatal protein extracts before addition of the radioactively labeled promoter elements dynAP-1 $(A, B)$, canonical AP-1 $(C, D)$, dynCRE3 $(E, F)$, and consensus $\mathrm{CRE}(G, H)$. The experiments were repeated at least three times with samples from different rats. In the left-hand pictures, $s 1$ and $s 2$ are protein extracts from intact striata of two chronically L-DOPA-treated rats, whereas $s 1^{\prime}$ and $s 2^{\prime}$ are extracts from the corresponding 6-OHDA-lesioned side. Rats treated with acute L-DOPA showed comparable results. In the right-hand pictures, $s, a$, and $c$ are protein extracts from animals treated with saline, acute cocaine, or chronic cocaine, respectively.

intrastriatal infusion of $f o s \mathrm{~B}$ antisense prevents PDyn gene induction by L-DOPA (Andersson et al., 1999). In the DAdenervated and L-DOPA-treated striatum, FosB/DFosB-related antigens were the main contributors to binding activity at each of the four enhancer elements under investigation (Fig. 9A,C,E, $G$ ). The CREB antiserum had no effect on the binding activity to the dynAP-1 and canonical AP-1 probes (Fig. 9A,C) and reduced the specific dynCRE3- and consensus CRE-binding to a much lesser 


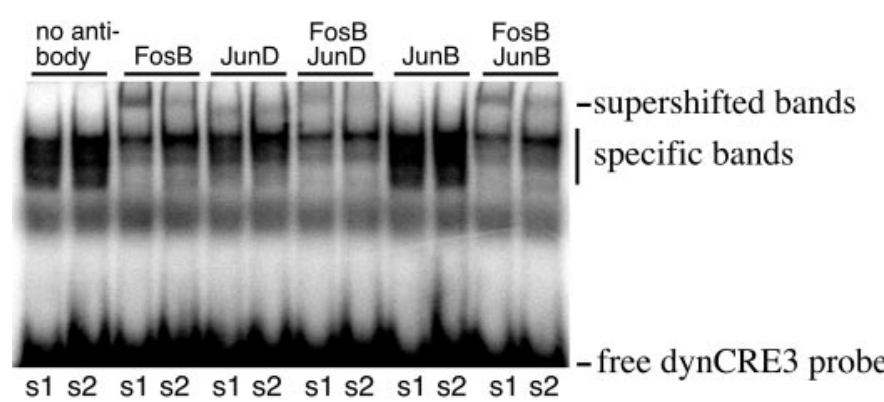

Figure 10. Like FosB/AFosB-related proteins, JunD can bind at AP-1 and CRE enhancers in 6-OHDA-lesioned, L-DOPA-treated rats. To characterize possible binding partners to $F o s B / \Delta F o s B$ proteins in the L-DOPA-induced dynCRE3 complex, supershift assays were performed with JunD or JunB antisera. $s 1$ and $s 2$ are samples from the lesioned striata of two L-DOPA-treated rats. This experiment was repeated with samples from additional animals, and with the dynAP-1 probe, it obtained similar results.

extent than the FosB antiserum did (Fig. 9E, $G$, lesion). This was in contrast to cocaine-treated animals, in which CREB was the major protein binding at the enhancer elements under investigation (Fig. 9D,F,H) (see results below).

Supershift analyses from acutely L-DOPA-treated rats produced identical results, i.e., FosB/ $\Delta$ FosB-related proteins were the main contributors to AP-1 and CRE binding in the DAdenervated striatum (data not shown). Because acute L-DOPA treatment induces c-Fos in addition to FosB, an antibody against c-Fos was also tested in supershift analysis. A small supershift at the canonical AP-1 oligonucleotide could be detected after acute L-DOPA treatment; however, c-Fos proteins did not contribute to the DNA binding activity at the other enhancer elements (data not shown).

Putative dimerization partners of FosB-related transcription factors are JunB and JunD proteins (Chen et al., 1995; Vallone et al., 1997). We thus performed a supershift analysis using JunB and JunD antibodies, alone or in combination with the FosB/ $\Delta$ FosB antiserum. Specific dynCRE3-containing complexes were displaced to some extent by the JunD antibody alone, and to an even larger extent by the JunD and FosB antibodies in combination (Fig. 10). In contrast, the JunB antibody did not displace any of the protein-DNA complexes, and the supershift produced by a combination of JunB and FosB/ $\Delta$ FosB antibodies was entirely accounted for by the latter (Fig. 10). This experiment was repeated with the dynAP-1 enhancer element with similar results.

\section{DNA binding activity in the intact striatum after treatment with cocaine}

In agreement with previous findings (Hope et al., 1994), both acute and chronic cocaine treatment induced an approximately twofold increase in striatal protein binding to the canonical AP-1 probe (Table 3, Fig. 9D, autoradiographs). DNA binding activity to the dynCRE3 enhancer was induced, albeit slightly, only after acute cocaine (Table 3 , Fig. $9 F$ ), whereas no induction was found at the consensus CRE element (Table 3, Fig. $9 H$ ). In agreement with previous findings (Cole et al., 1995), striatal protein binding to the dynAP-1 promoter element could not be detected (Fig. 9B).

The CREB antiserum supershifted the specific bands not only from the dynCRE3 and consensus CRE (Fig. $9 F, H$ ) but also from the canonical AP-1 enhancer element (Fig. 9D). The FosB/ $\Delta$ FosB antibody produced only a minor displacement of the specific
AP-1 bands, which was much less pronounced than that seen in the 6-OHDA-lesioned and L-DOPA treated striatum (Fig. 9, compare $C, D)$. A c-Fos antiserum was found to supershift small amounts of the AP-1 complex induced by acute cocaine treatment (data not shown).

\section{FosB/ $\Delta$ FosB proteins are expressed at a higher level in the L-DOPA-treated striatum}

The data presented so far revealed dramatic differences between L-DOPA- and cocaine-induced striatal DNA binding activity, in terms of which elements within the PDyn promoter were activated and which proteins were bound to them. These data raised the question of whether the difference between the two drug treatment paradigms could be attributed to a differential induction of $F o s B / \Delta$ FosB-related proteins on a quantitative or qualitative level. Striatal protein extracts therefore were analyzed by Western immunoblotting using two different FosB/DFosB antisera (see Materials and Methods). Both antisera showed striatal induction of $\mathrm{FosB} / \Delta$ FosB-immunoreactive bands with the same molecular weight (i.e., 33 and $35-37 \mathrm{kDa}$ ) after treatment with cocaine and L-DOPA (Fig. 11 $A$ ). However, the levels of induction were significantly higher in the L-DOPA-treated animals (Fig. $11 B)$. These results were confirmed using an antiserum that recognizes all Fos family proteins (Fig. 11C) and were consistent with the results obtained in the quantitative immunohistochemical analysis (compare FosB-positive cell numbers after treatment with $8 \mathrm{mg} / \mathrm{kg}$ L-DOPA or $30 \mathrm{mg} / \mathrm{kg}$ cocaine in Figs. $2 B$ and $5 B$ ).

\section{DISCUSSION}

Current knowledge of DA agonist-induced signaling pathways is mainly derived from studies performed in neurologically intact animals and cultured neurons. However, conclusions from these model systems may not be applicable to the DA-denervated striatum. Indeed, DA denervation causes profound changes in the expression, functional coupling, and state of phosphorylation of striatal DA and glutamate receptors (Narang and Wamsley, 1990; LaHoste and Marshall, 1992; Dunah et al., 2000; and see references therein), all of which are critical for DA-dependent nuclear signaling (Graybiel et al., 1990; Konradi et al., 1996).

In this study, we have used an antisense approach to verify the requirement of $\mathrm{CREB}$ for striatal PDyn and fos family gene induction, as produced by L-DOPA in DA-denervated rats and cocaine in neurologically intact animals. Knowing that the response to DA agonists is supersensitive in parkinsonian subjects (see below), L-DOPA was titrated to just above the threshold dose for induction of the genes under investigation. The doses of L-DOPA tested here $(3-8 \mathrm{mg} / \mathrm{kg}$ ) are in the range used for the treatment of Parkinson's disease. Cocaine was tested at $15 \mathrm{mg} / \mathrm{kg}$, a typical bolus dose in "binge" cocaine studies in rats (QuinonesJenab et al., 2000; Rosin et al., 2000), and at $30 \mathrm{mg} / \mathrm{kg}$, a dose that is among the highest used in the literature (Steiner and Gerfen, 1993) and approximates half the $\mathrm{LD}_{50}$ for cocaine in rats (Derlet et al., 1990).

In the first part of the study we used a single-injection method for intrastriatal CREB antisense delivery. Because single antisense injections may not be able to block gene expression changes by strong inducing stimuli (Konradi et al., 1994), we also examined the effects of continuous antisense infusion for $14 \mathrm{~d}$. The two methods of antisense delivery produced identical results: CREB knockdown reduced basal and cocaine-induced PDyn, $c$-fos, and fos $\mathrm{B}$ gene expression in the intact caudate-putamen but had no 


\begin{tabular}{llll}
\hline \multicolumn{2}{l}{ Table 3. Cocaine-induced DNA binding activity } & \\
& Canonical & & Consensus \\
Treatment & AP-1 & dynCRE3 & CRE \\
\hline Saline & $1.00 \pm 0.04$ & $1.00 \pm 0.03$ & $1.00 \pm 0.04$ \\
Acute cocaine & $1.97 \pm 0.21^{*}$ & $1.42 \pm 0.11^{*}$ & $0.96 \pm 0.04$ \\
Chronic cocaine & $1.70 \pm 0.20^{*}$ & $1.25 \pm 0.10$ & $0.94 \pm 0.04$
\end{tabular}

Cocaine induces DNA binding activity to the canonical AP-1 and dynCRE promoter element, but not to the consensus CRE or the dynAP-1 probe (data not shown). The data are expressed as fold induction relative to saline-treated controls. This experiment was repeated twice with samples from different animals; ${ }^{*} p<0.05$ versus saline group; $n=5$ in each group.

effect on the gene expression changes produced by L-DOPA in the 6-OHDA-lesioned striatum.

A tight coupling between levels of CREB activity and PDyn gene expression in intact striatal neurons has been demonstrated previously with herpes virus-mediated gene transfer of native or mutated CREB in the nucleus accumbens (Carlezon et al., 1998). Here we demonstrate that in the sensorimotor striatum CREB is indeed required for basal PDyn expression as well as for the induction of PDyn by cocaine. In contrast, in the DA-denervated striatum, transcription factors other than CREB, such as $\Delta$ FosBlike proteins and JunD, are paramount for the regulation of PDyn.

In the rat Parkinson model, upregulation of striatal PDyn mRNA by L-DOPA is tightly associated with the development of dyskinesia (Cenci et al., 1998). Accordingly, the present study shows a close correlation between AIM scores induced by chronic L-DOPA treatment and striatal DNA binding activity at AP-1 and CRE-like sites in the PDyn promoter (note, however, that an increase in DNA binding activity was also detected in the acute L-DOPA cases, which did not exhibit significant dyskinesia). The importance of PDyn upregulation as a determinant of AIM development is further supported by the anti-dyskinetic effect of treatments that block or prevent striatal PDyn gene induction during chronic L-DOPA treatment (Andersson et al., 1999; Henry et al., 1999; Lee et al., 2000) (and our unpublished data). It is therefore not surprising that striatal knockdown of CREB, which did not block PDyn gene induction by L-DOPA, was ineffective in reducing dyskinesia. On the contrary, CREB knockdown caused an even greater sensitivity to the dyskinesiogenic effect of L-DOPA in 6-OHDA-lesioned rats. Hyperkinetic effects of CREB knockdown occurred also in intact animals, which showed increased motor activation after a stressful stimulus (saline injection). Because this response occurred in the absence of any drug treatment, it is most likely caused by altered regulation of striatal genes that depend on CREB for their basal expression. Indeed, CREB has been shown to maintain constitutive expression of several genes in various tissues, including brain (for review, see Herdegen and Leah, 1998), and basal levels of CREB phosphorylation are found in the striatum (Sgambato et al., 1998). In intact animals injected with cocaine, CREB knockdown did not significantly augment the stereotypic behavior induced by the treatment. This lack of effect may depend on two factors. First, in the cocaine paradigm, CREB knockdown produces two parallel phenomena that are likely to affect motor behavior in opposite directions, namely, a dysregulation of constitutively expressed, CREB-dependent genes, and a blockade of cocaine-induced gene expression. Second, the motor response to cocaine in intact rats involves DA-receptor stimulation in the striata of both sides. Indeed, unilateral injections of DA agonists in the lateral $\mathrm{CPu}$ have been shown to produce stereotypies half as intense as those elicited by bilateral injections (Dickson et al., 1994). Thus, bilateral knockdown of CREB may be required to fully uncover its role in cocaine-induced stereotypies.

DA-dependent expression of c-Fos and PDyn has been shown to require activation of CRE- and AP-1-like enhancers in the corresponding promoters (Naranjo et al., 1991; Konradi et al., 1994; Cole et al., 1995). We therefore performed a study of DNA-protein interactions at consensus CRE and AP-1 sites in

\section{A FosB $/ \triangle$ FosB}

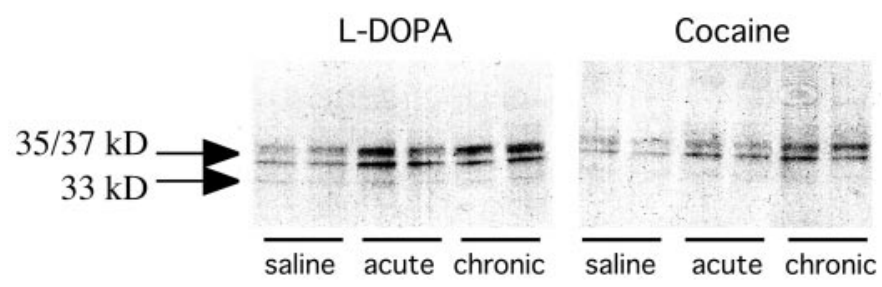

\section{B FosB/ $\Delta$ FosB levels}
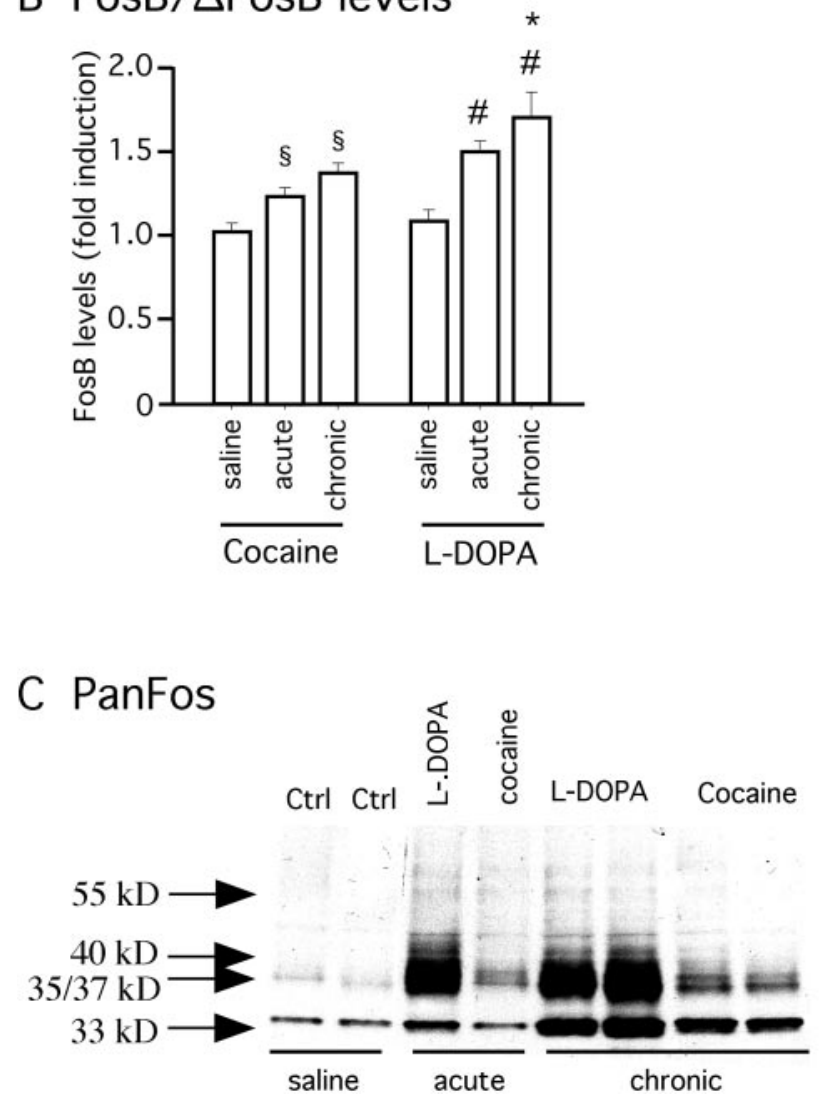

Figure 11. L-DOPA induces FosB/ $\Delta$ FosB proteins to a higher level than cocaine does. Immunoblots with an antibody to FosB $/ \Delta$ FosB are shown in $A$, and the corresponding densitometric analysis is shown in $B$. All the immunoblots used for analysis were processed simultaneously. A representative immunoblot stained with a PanFos antibody is shown in $C$. Arrows indicate the expected molecular weights of c-Fos $(55 \mathrm{kDa}), \Delta \mathrm{FosB}$ $(33 \mathrm{kDa})$, and the chronic FRAs $(35-37 \mathrm{kDa}) .{ }^{*} p<0.001$ versus saline, acute cocaine, and chronic cocaine group. ${ }^{\circledR} p<0.05$ versus saline controls in the cocaine paradigm. ${ }^{\#} p<0.01$ versus saline controls in the L-DOPA paradigm; $n \geq 5$; values give means + SEM. 
the two drug treatment paradigms under investigation. Because DNA binding affinity depends not only on the DNA binding site per se but also on the adjacent bases (Ryseck and Bravo, 1991), we also used DNA probes reproducing an AP-1-like site and a CRE-like element from the PDyn promoter. Both enhancers have been found to mediate transactivation of the PDyn gene in cell cultures (Naranjo et al., 1991; Messersmith et al., 1994). Both L-DOPA and cocaine were found to increase AP-1 binding to the canonical AP-1 site, whereas increased binding to the consensus CRE was detected only in L-DOPA-treated rats. At the PDyn promoter, both cocaine and L-DOPA induced protein binding to the dynCRE3 element, although this increase was much larger in the 6-OHDA/L-DOPA model. Moreover, only L-DOPA induced any binding to the dynAP-1. An analysis of the protein composition of the induced protein-DNA complexes provides an explanation for the observed differences between drug treatment paradigms. In intact rats treated with cocaine, striatal DNA binding activity was mainly accounted for by CREB, which is constitutively expressed and is thought to bind to the DNA regardless of its phosphorylation state (for review, see Shaywitz and Greenberg, 1999). In 6-OHDA-lesioned animals treated with L-DOPA, $\Delta$ FosB-related proteins, in combination with JunD, were the main contributors to striatal AP-1- and CRE-binding activity and could target both CRE- and AP-1-like sites in the PDyn promoter.

AP-1 complexes containing FosB and JunD have been shown to bind consensus CREs in vitro (Ryseck and Bravo, 1991). Our data show that such a phenomenon can occur in vivo in a specific pathophysiological condition, i.e., the parkinsonian striatum treated with a therapeutic dose of L-DOPA. As shown by Western blot analysis, striatal expression of $\Delta$ FosB $(\sim 33 \mathrm{kDa})$ and its derivatives, the so-called chronic FRAs $(\sim 35-37 \mathrm{kDa})$ (Hope et al., 1994), was induced to a much larger extent by L-DOPA in DA-denervated rats than by cocaine in intact animals. These high levels of expression, which reflect a condition of DA-receptor supersensitivity at the gene induction level (for review, see Gerfen, 2000), seem to enable $\Delta$ FosB-like proteins to compete for and regulate consensus CREs, in addition to AP-1 sites. Our data show that JunD can also bind to these sites, presumably after dimerization with the induced $\Delta$ FosB-like proteins (Vallone et al., 1997; Pérez-Otaño et al., 1998).

We propose that, in the parkinsonian striatum treated with L-DOPA, dimers of $\triangle$ FosB-like proteins and JunD can bypass CREB in the transactivation of PDyn and fos family genes. Indeed, intrastriatal knockdown of fosB (Andersson et al., 1999) but not CREB (present study) blocks the striatal induction of PDyn by L-DOPA. A switch from CREB- to $\triangle \mathrm{FosB} / \mathrm{chronic}$ FRAs-driven gene activation may explain the magnitude and peculiar dynamics of the supersensitive gene induction response, which is seen in the DA-denervated striatum after treatment with DA agonists. Indeed, $\Delta$ FosB-JunD dimers have a much longer half-life than phosphorylated CREB (for review, see Herdegen and Leah, 1998) and persist at very high levels both during and after long-term treatment with L-DOPA (Westin et al., 2001) (and our unpublished data). Accordingly, DA-agonist treatment to 6-OHDA-lesioned rats has been shown to produce a persistent striatal induction of both PDyn and early response genes (Steiner and Gerfen, 1996; Westin et al., 2001). This persistent induction reflects the breakdown of homeostatic mechanisms that would normally limit the gene expression changes produced by repeated DA-agonist administration, as determined by studies performed in intact animals (Steiner and Gerfen, 1993; for review, see Gerfen, 2000).

In conclusion, by combining in vivo gene induction assays and antisense technology, this study demonstrates that CREB is essential for the expression of PDyn and fos family genes in intact but not DA-denervated striatal neurons. In the latter, L-DOPAinduced $\Delta$ FosB-like proteins, in combination with JunD, can compete with CREB for binding to consensus CRE sites. Thus, these data uncover a novel and unexpected alteration of transcriptional regulatory mechanisms that occurs in the supersensitive parkinsonian striatum treated with L-DOPA.

\section{REFERENCES}

Andersson M, Hilbertson A, Cenci MA (1999) Striatal fosB expression is causally linked with L-DOPA-induced abnormal involuntary movements and the associated upregulation of striatal prodynorphin mRNA in a rat model of Parkinson's disease. Neurobiol Dis 6:461-474.

Calon F, Tahar AH, Blanchet PJ, Morissette M, Grondin R, Goulet M, Doucet JP, Robertson GS, Nestler E, Di Paolo T, Bedard PJ (2000) Dopamine-receptor stimulation: biobehavioral and biochemical consequences. Trends Neurosci 23:S92-100.

Carlezon Jr WA, Thome J, Olson VG, Lane-Ladd SB, Brodkin ES, Hiroi N, Duman RS, Neve RL, Nestler EJ (1998) Regulation of cocaine reward by CREB. Science 282:2272-2275.

Cenci MA, Lee CS, Björklund A (1998) L-DOPA-induced dyskinesia in the rat is associated with striatal overexpression of prodynorphin- and glutamic acid decarboxylase mRNA. Eur J Neurosci 10:2694-2706.

Cenci MA, Tranberg A, Andersson M, Hilbertson A (1999) Changes in the regional and compartmental distribution of FosB- and JunB-like immunoreactivity induced in the dopamine-denervated rat striatum by acute or chronic L-DOPA treatment. Neuroscience 94:515-527.

Chen J, Nye HE, Kelz MB, Hiroi N, Nakabeppu Y, Hope BT, Nestler EJ (1995) Regulation of DFosB and FosB-like proteins by electroconvulsive seizure and cocaine treatments. Mol Pharmacol 48:880-889.

Civelli O, Douglass J, Goldstein A, Herbert E (1985) Sequence and expression of the rat prodynorphin gene. Proc Natl Acad Sci USA 82:4291-4295.

Cole DG, Kobierski LA, Konradi C, Hyman SE (1994) 6-Hydroxydopamine lesions of rat substantia nigra up-regulate dopamine-induced phosphorylation of the cAMP-response elementbinding protein in striatal neurons. Proc Natl Acad Sci USA 91:9631-9635.

Cole RL, Konradi C, Douglass J, Hyman SE (1995) Neuronal adaptation to amphetamine and dopamine: molecular mechanisms of prodynorphin gene regulation in rat striatum. Neuron 14:813-823.

Collins-Hicok J, Lin L, Spiro C, Laybourn PJ, Tschumper R, Rapacz B, McMurray CT (1994) Induction of the rat prodynorphin gene through Gs-coupled receptors may involve phosphorylation-dependent derepression and activation. Mol Cell Biol 14:2837-2848.

Creese I, Iversen SD (1973) Blockage of amphetamine induced motor stimulation and stereotypy in the adult rat following neonatal treatment with 6-hydroxydopamine. Brain Res 55:369-382.

Curran T, Gordon MB, Rubino KL, Sambucetti LC (1987) Isolation and characterization of the c-fos(rat) cDNA and analysis of posttranslational modification in vitro. Oncogene 2:79-84.

Derlet RW, Albertson TE, Rice P (1990) Antagonism of cocaine, amphetamine, and methamphetamine toxicity. Pharmacol Biochem Behav 36:745-749.

Dickson PR, Lang CG, Hinton SC, Kelley AE (1994) Oral stereotypy induced by amphetamine microinjection into striatum: an anatomical mapping study. Neuroscience 61:81-91.

Doucet JP, Nakabeppu Y, Bedard PJ, Hope BT, Nestler EJ, Jasmin BJ, Chen JS, Iadarola MJ, St-Jean M, Wigle N, Blanchet P, Grondin R, Robertson GS (1996) Chronic alterations in dopaminergic neurotransmission produce a persistent elevation of deltaFosB-like protein(s) in both the rodent and primate striatum. Eur J Neurosci 8:365-381.

Douglass J, McKinzie AA, Pollock KM (1994) Identification of multiple DNA elements regulating basal and protein kinase A-induced transcriptional expression of the rat prodynorphin gene. Mol Endocrinol 8:333-344.

Dunah AW, Wang Y, Yasuda RP, Kameyama K, Huganir RL, Wolfe BB, Standaert DG (2000) Alterations in subunit expression, composition, and phosphorylation of striatal $N$-methyl-D-aspartate glutamate receptors in a rat 6-hydroxydopamine model of Parkinson's disease. Mol Pharmacol 57:342-352.

Gerfen CR (2000) Molecular effects of dopamine on striatal-projection pathways. Trends Neurosci 23:S64-70.

Graybiel AM, Moratalla R, Robertson HA (1990) Amphetamine and cocaine induce drug-specific activation of the c-fos gene in striosome- 
matrix compartments and limbic subdivisions of the striatum. Proc Natl Acad Sci USA 87:6912-6916.

Graybiel AM, Canales JJ, Capper-Loup C (2000) Levodopa-induced dyskinesias and dopamine-dependent stereotypies: a new hypothesis. Trends Neurosci 23:S71-77.

Henry B, Crossman AR, Brotchie JM (1999) Effect of repeated L-DOPA, bromocriptine, or lisuride administration on preproenkephalin-A and preproenkephalin-B mRNA levels in the striatum of the 6-hydroxydopamine-lesioned rat. Exp Neurol 155:204-220.

Herdegen T, Leah JD (1998) Inducible and constitutive transcription factors in the mammalian nervous system: control of gene expression by Jun, Fos and Krox, and CREB/ATF proteins. Brain Res Rev 28:370-490.

Hope BT, Nye HE, Kelz MB, Self DW, Iadarola MJ, Nakabeppu Y, Duman RS, Nestler EJ (1994) Induction of a long-lasting AP-1 complex composed of altered Fos-like proteins in brain by chronic cocaine and other chronic treatments. Neuron 13:1235-1244.

Howells RD, Kilpatrick DL, Bhatt R, Monahan JJ, Poonian M, Udenfriend S (1984) Molecular cloning and sequence determination of rat preproenkephalin cDNA: sensitive probe for studying transcriptional changes in rat tissues. Proc Natl Acad Sci USA 81:7651-7655.

Hurd YL, Herkenham M (1992) Influence of a single injection of cocaine, amphetamine or GBR 12909 on mRNA expression of striatal neuropeptides. Mol Brain Res 16:97-104.

Kashihara K, Akiyama K, Ishihara T, Shiro Y, Shohmori T (1996) Levodopa but not bromocriptine induces AP-1 and creb DNA-binding activity in the dopamine-depleted striatum of the rat. Life Sci 58:L159-170.

Kobayashi Y, Kaufman DL, Tobin AJ (1987) Glutamic acid decarboxylase cDNA: nucleotide sequence encoding an enzymatically active fusion protein. J Neurosci 7:2768-2772.

Konradi C, Heckers S (1995) Haloperidol-induced Fos expression in striatum is dependent upon transcription factor cyclic AMP response element binding protein. Neuroscience 65:1051-1061.

Konradi C, Kobierski LA, Nguyen TV, Heckers S, Hyman SE (1993) The cAMP-response-element-binding protein interacts, but Fos protein does not interact, with the proenkephalin enhancer in rat striatum. Proc Natl Acad Sci USA 90:7005-7009.

Konradi C, Cole RL, Heckers S, Hyman SE (1994) Amphetamine regulates gene expression in rat striatum via transcription factor CREB. J Neurosci 14:5623-5634.

Konradi C, Leveque JC, Hyman SE (1996) Amphetamine and dopamine-induced immediate early gene expression in striatal neurons depends on postsynaptic NMDA receptors and calcium. J Neurosci 16:4231-4239.

LaHoste GJ, Marshall JF (1992) Dopamine supersensitivity and D1/D2 synergism are unrelated to changes in striatal receptor density. Synapse $12: 14-26$.

Lee CS, Cenci MA, Schulzer M, Bjorklund A (2000) Embryonic ventral mesencephalic grafts improve levodopa-induced dyskinesia in a rat model of Parkinson's disease. Brain 123:1365-1379.

Messersmith DJ, Gu J, Dubner R, Douglass J, Iadarola MJ (1994) Basal and inducible transcriptional activity of an upstream AP-1/CRE element (DYNCRE3) in the prodynorphin promoter. Mol Cell Neurosci $5: 238-245$.

Monsma Jr FJ, Mahan LC, McVittie LD, Gerfen CR, Sibley DR (1990) Molecular cloning and expression of a D1 dopamine receptor linked to adenylyl cyclase activation. Proc Natl Acad Sci USA 87:6723-6727.

Narang N, Wamsley JK (1990) Time dependent changes in DA uptake sites, D1 and D2 receptor binding and mRNA after 6-OHDA lesions of the medial forebrain bundle in the rat brain. J Chem Neuroanat 9:41-53.

Naranjo JR, Mellström B, Achaval M, Sassone-Corsi P (1991) Molecular pathways of pain: Fos/Jun-mediated activation of a noncanonical AP-1 site in the prodynorphin gene. Neuron 6:607-617.

Paxinos G, Watson C (1997) The rat brain in stereotaxic coordinates. San Diego: Academic.

Pérez-Otaño I, Mandelzys A, Morgan JI (1998) MPTP-Parkinsonism is accompanied by persistent expression of D-FosB-like proteins in dopaminergic pathways. Mol Brain Res 53:41-52.

Pierce RC, Kalivas PW (1997) A circuitry model of the expression of behavioral sensitization to amphetamine-like psychostimulants. Brain Res Brain Res Rev 25:192-216.

Quinones-Jenab V, Krey LC, Schlussman SD, Ho A, Kreek MJ (2000) Chronic "binge" pattern cocaine alters the neuroendocrine profile of pregnant rats. Neurosci Lett 282:120-122.

Rosin A, van der Ploeg I, Georgieva J (2000) Basal and cocaine-induced opioid receptor gene expression in the rat CNS analyzed by competitive reverse transcription PCR. Brain Res 872:102-109.

Ryseck RP, Bravo R (1991) c-JUN, JUN B, and JUN D differ in their binding affinities to AP-1 and CRE consensus sequences: effect of FOS proteins. Oncogene 6:533-542.

Schmidt RH, Ingvar M, Lindvall O, Stenevi U, Björklund A (1982) Functional activity of substantia nigra grafts reinnervating the striatum: neurotransmitter metabolism and $\left[{ }^{14} \mathrm{C}\right]$ 2-deoxy-D-glucose autoradiography. J Neurochem 38:737-748.

Schmued LC, Hopkins KJ (2000) Fluoro-Jade B: a high affinity fluorescent marker for the localization of neuronal degeneration. Brain Res 874:123-130.

Sgambato V, Pages C, Rogard M, Besson MJ, Caboche J (1998) Extracellular signal-regulated kinase (ERK) controls immediate early gene induction on corticostriatal stimulation. J Neurosci 18:8814-8825.

Shaywitz AJ, Greenberg ME (1999) CREB: a stimulus-induced transcription factor activated by a diverse array of extracellular signals. Annu Rev Biochem 68:821-861.

Simpson JN, McGinty JF (1995) Forskolin induces preproenkephalin and preprodynorphin mRNA in rat striatum as demonstrated by in situ hybridization histochemistry. Synapse 19:151-159.

Steiner H, Gerfen CR (1993) Cocaine-induced c-fos messenger RNA is inversely related to dynorphin expression in striatum. J Neurosci 13:5066-5081.

Steiner H, Gerfen CR (1996) Dynorphin regulates D1 dopamine receptor-mediated responses in the striatum: relative contributions of pre- and postsynaptic mechanisms in dorsal and ventral striatum demonstrated by altered immediate-early gene induction. J Comp Neurol 376:530-541.

Vallone D, Pellecchia MT, Morelli M, Verde P, DiChiara G, Barone P (1997) Behavioral sensitization in 6-hydroxydopamine-lesioned rats is related to compositional changes of the AP-1 transcription factor: evidence for the induction of FosB- and JunD-related proteins. Mol Brain Res 52:307-317.

Wang JB, Johnson PS, Imai Y, Persico AM, Ozenberger BA, Eppler CM, Uhl GR (1994) cDNA cloning of an orphan opiate receptor gene family member and its splice variant. FEBS Lett 348:75-79.

Westin J, Andersson M, Lundblad M, Cenci MA (2001) Persistence of changes in striatal gene expression induced by long-term L-DOPA treatment in a rat model of Parkinson's disease. Eur J Neurosci 14 1171-1176. 